\title{
Michigan Michigan Michigan
}

\section{Courtney Brown}

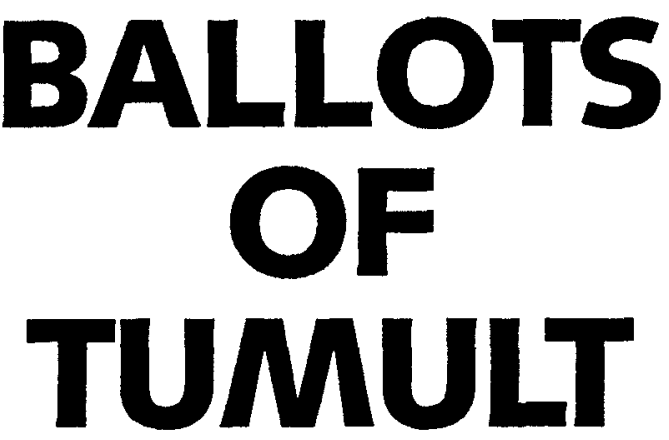

\section{A Portrait of Volatility in American Voting}

Ballots of Tumult examines the dynamics of explosive and large-scale electoral change in the United States throughout the twentieth century. Brown uses sophisticated new analy tic techniques to analyze electoral and census data. The result is a challenge to the conventional wisdom about the stability of American politics and and new insights into their surprising volatility.

"Ballots of Tumult is a healthy shift, a return to the study of 'real politics,' the study of winners and losers in the struggle for electoral power." -Michael S. Lewis-Beck, University of Iowa

"... an extremely original piece of research." -Alan Abramowitz, Emory University

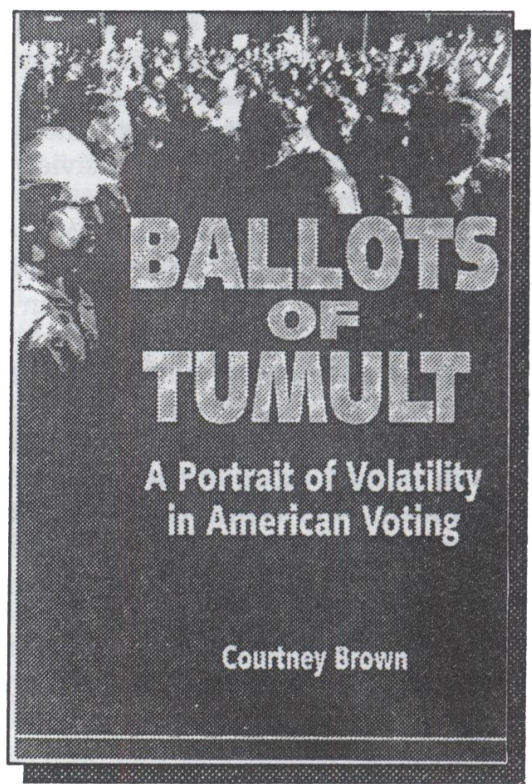

"... a book all students of American Politics should read ....

-Iohn Sprague, Washington University

"This seminal work is must reading for anyone interested in women and politics. It casts doubts on long held assumptions about women's voting patterns and has fascinating implications for the study of the new gender gap that has occurred in recent years." -Karen O'Connor, President, Women's Caucus for Political Science, 1990-91

cloth $\$ 34.50$

\section{An THE UNIVERSITY OF MICHIGAN Michigan Press}

Dept. PY Ann Arbor, Michigan 48106-1104 


\section{POLITICAL PERSPECTIVES}

Federal Domestic Outlays, 1983-1990

A Data Book

Kenneth N. Bickers and Robert M. Stein

304 pages Hardcover $\$ 45.00$

Do Elections Matter?

Second Edition

Edited by Benjamin Ginsberg and Alan Stone

272 pages Hardcover $\$ 45.95$ Paper $\$ 15.95$

The National Party Chairmen

and Committees

Factionalism at the Top

Ralph M. Goldman

624 pages Hardcover $\$ 60.00$

The Atomistic Congress

An Interpretation of Congressional Change

Edited by Allen D. Hertzke and Ronald M. Peters, Jr.

256 pages Hardcover $\$ 39.95$

Perestroika-era Politics:

The New Soviet Legislature

and Gorbachev's Political Reforms

Edited by Robert T. Huber and Donald R. Kelley

Contemporary Soviet Politics

256 pages Hardcover $\$ 45.00$ Paper $\$ 13.95$

The Study of Welfare State Regimes

Jon Eivind Kolberg, editor

Comparative Public Policy Analysis Series

256 pages Hardcover $\$ 42.50$

Between Work and Social Citizenship

Jon Eivind Kolberg, editor

Comparative Public Policy Analysis Series

216 pages Hardcover $\$ 42.50$

The Welfare State as Employer

Jon Eivind Kolberg, editor

Comparative Public Policy Analysis Series

216 pages Hardcover $\$ 42.50$

Losing Balance

The De-Democratization of America

William P. Kreml

180 pages Hardcover $\$ 29.95$

\section{The Data Game}

Controversies in Social Science Statistics

Mark H. Maier

256 pages Hardcover $\$ 39.95$ Paper $\$ 13.95$

All of the People, All the Time

Strategic Communication and

American Politics

Jarol B. Manheim

288 pages Hardcover $\$ 25.00$
Essays of a Citizen

From National Security State to Democracy

Marcus G. Raskin

330 pages Hardcover $\$ 27.50$

\section{Political Ideologies}

A Comparative Approach

Mostafa Rejai

220 pages Hardcover $\$ 35.00$ Paper $\$ 12.95$

Perestroika at the Crossroads

Edited by Alfred J. Rieber

and Alvin Z. Rubinstein

352 pages Hardcover $\$ 49.95$ Paper $\$ 16.95$

State Security in South Africa

Civil-Military Relations under P W Botha

James M. Roherty

December 256 pages Hardcover $\$ 39.95$

Assets and the Poor

A New American Welfare Policy

Michael Sherraden

344 pages Hardcover $\$ 34.95$

The Shape of the Future

The Post-Cold War World

Donald M. Snow

256 pages Hardcover $\$ 35.00$ Paper $\$ 15.00$

International Law and Security

Military and Political Dimensions

A U.S.-Soviet Dialogue

Edited by Paul B. Stephan III and Boris M. Klimenko

384 pages Hardcover $\$ 59.95$

The Road to Disillusion:

From Critical Marxism to Post-Communism

in Eastern Europe

Edited by Raymond Taras

November 300 pages Hardcover $\$ 39.95$

Exploring Revolution

Essays on Latin American Insurgency

and Revolutionary Theory

Timothy P. Wickham-Crowley

224 pages Hardcover $\$ 35.00$

Controversies in Soviet Social Thought

Democratization, Social Justice,

and the Erosion of Official Idealogy

Murray Yanowitch

176 pages Hardcover $\$ 35.00$ Paper $\$ 12.95$

\section{E. Sharpe, Inc,}

80 Business Park Drive, Armonk, NY 10504 • Call 1-800-541-6563 • Fax 914-273-2106

MasterCard and VISA accepted. 


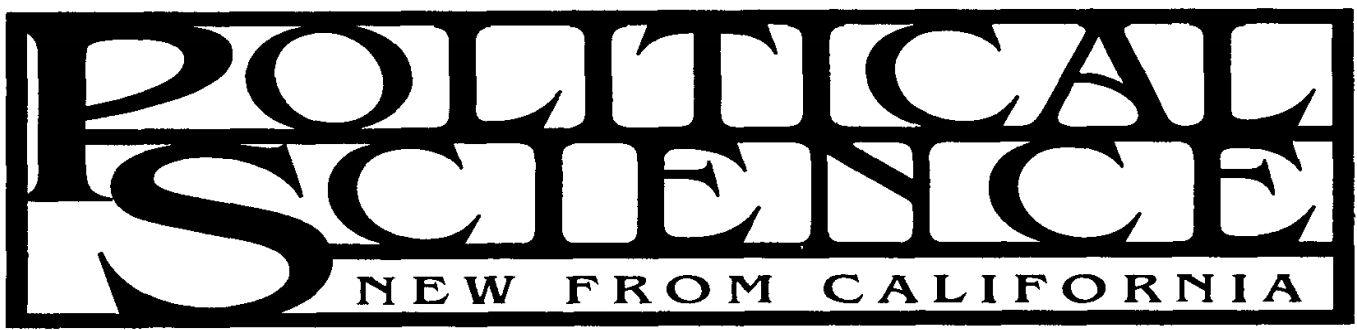

\section{America at Century's End}

\section{Edited by ALAY WOLFE}

"The authors of this collection of firstrate essays cast a cold and critical eye on the present state of American society, and provide multiple clues to theoriginsand causes of our current predicaments." $\$ 29.95$ cloth, 567 pages, A Centennial Book -Lewis Coser

\section{Women of the Klan}

Racism and Gender in the 1920s

KATHILEEN M. BLEE

"Probably no future history of the Ku Klux Klan will be written without reference to this groundbreaking work."-Publishers Weekly

"A remarkable, nuanced, and deeply disturbing book."

Sara M. Evans, author of Born for Liberty $\$ 24.95$ cloth, 236 pages, illustrated

A Centennial Book

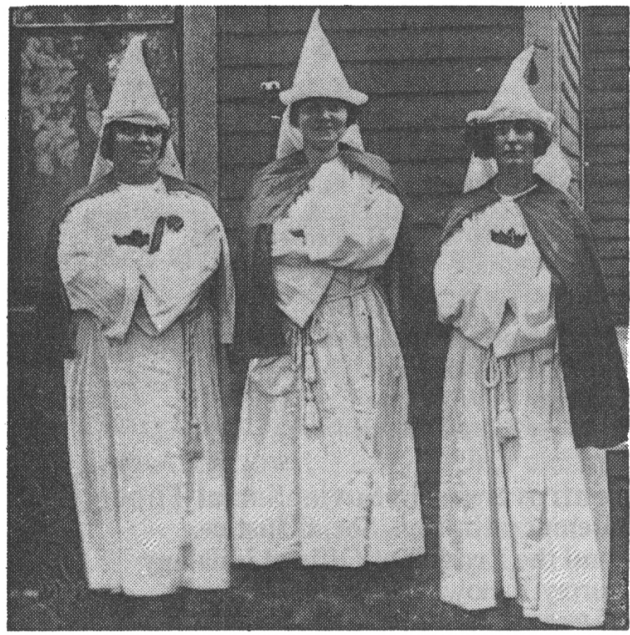

\section{Woodrow Wilson}

A Life for World Peace

J. W. SCHULTE NORDHOLT

Schulte Nordholt writes with deep understanding and empathy about America's 28th president. His Woodrow Wilson embodies the French proverb that great qualities and defects are inseparably joined.

$\$ 34.95$ cloth, 575 pages, illustrated

\section{In the Name of Democracy}

U. S. Policy Toward Latin America in the Reagan Years

\section{THOMAS CAROTHERS}

"A well written and significant book ... [ with] much material in it that is not available anywhere else."-Paul E. Sigmund, Princeton University $\$ 29.95$ cloth, 350 pages, illustrated

\section{Authoritarian Socialism in America}

Edward Bellamy and the Nationalist

Movement

With a new preface

ARTHUR LIPOW

New in paper--"This is an important book, vital to our understanding of the development of socialism in America."

-Joumal of American Studies

"Lipow brilliantly distinguishes the socialism one wants from that one resists."-New Statesman $\$ 13.95$ paper, 332 pages

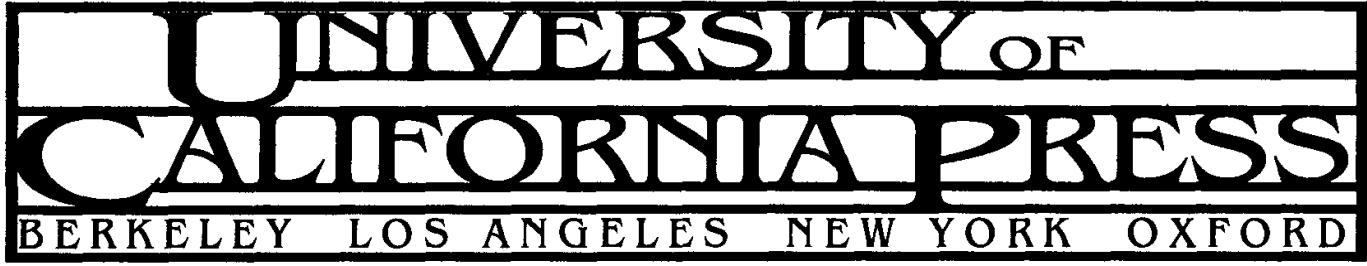




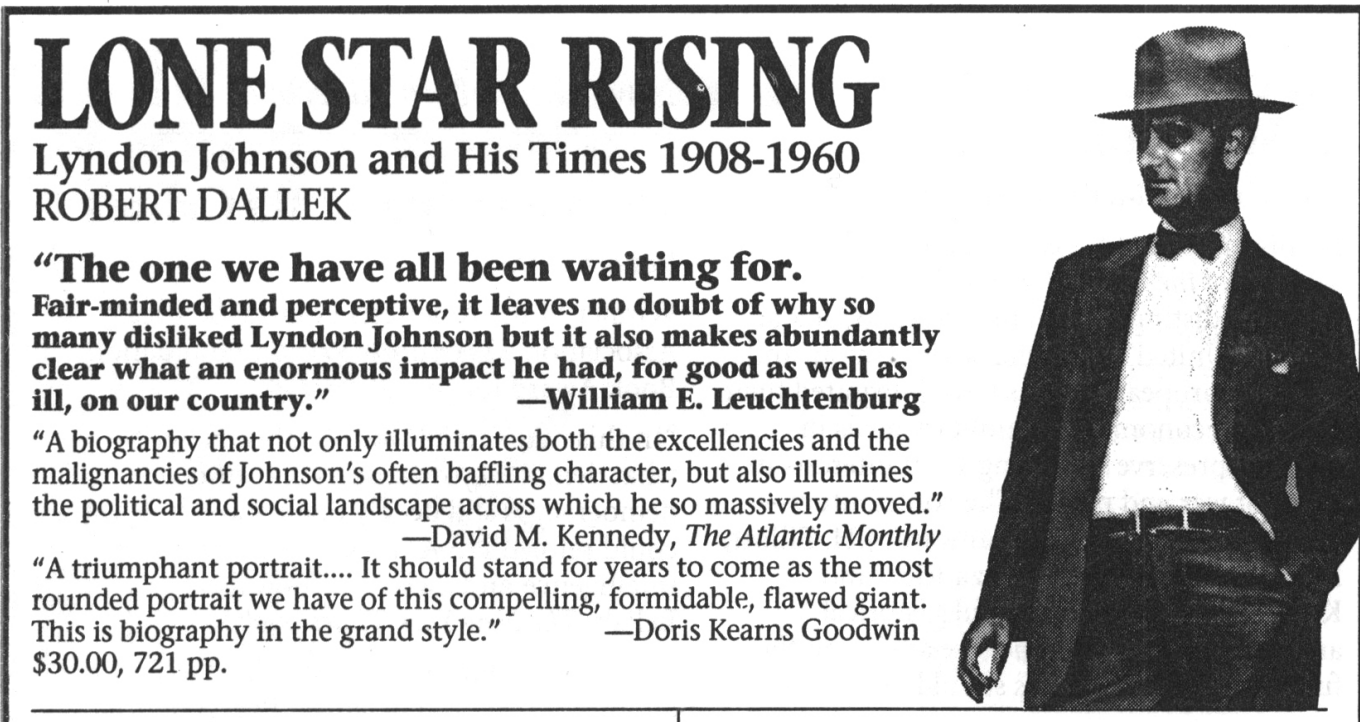

\section{INSIDE THE COLD WAR}

\section{Loy Henderson and the Rise} of the American Empire

H.W. BRANDS

"Scholars should welcome this well-written and well-researched biography of an important but often neglected framer of U.S. foreign policy during the mid-20th century.... Taking care to review the larger societal and global context in which Henderson operated, Brands shows how this staunch Cold Warrior's life reflected the moment when the United States abandoned its isolationism and became a world power." - Library Journal $\$ 29.95,337$ pp.

THE ASCENDANCE OF ISRAEL'S RADICAL RIGHT EHUD SPRINZAK

"Sprinzak is widely recognized as among the world's foremost scholars on Israeli politics. His exhaustive research and first-hand interviews with the major figures on the Israeli Right come together in this particularly thoughtful and thought-provoking book." - Robin Wright "The most outstanding and extraordinary study of contemporary Israel's radical right movement." -Amos Perlmutter "A thorough study.... Sprinzak provides unprecedented coverage." $\quad$-Kirkus Reviews $\$ 29.95 .320 \mathrm{pp}$.

\section{CONGRESSIONAL ANECDOTES}

\section{PAUL BOLLER}

"This latest collection of stories about the

\section{BREAKING THE BARRIER}

\section{The Rise of Solidarity in Poland LAWRENCE GOODWYN}

"The bitter confrontation between Solidarity and the Polish Communist government as presented by Goodwyn makes for an absorbing and illuminating tale. He has not been satisfied merely to interleaf chronology with shrewd analytical judgments, but also has done fascinating sketches of the Gdansk shipyard workers and Warsaw dissident intellectuals.... That they come to life on these pages makes Goodwyn's work an invaluable record of a unique time." $\$ 27.95,466$ pp.

$$
\text { -Dusko Doder, The Chicago Tribune }
$$
distinguished and not-so-distinguished individuals who have served in Congress offers not only laughs, but a feeling for the texture of life in Washington over 200 years." -Bill Bradley "If you love Congress, you'll love Congressional Anecdotes. If you hate Congress, you' ll love

Congressional Anecdotes." -Pat Schroeder $\$ 22.95$, $400 \mathrm{pp}$.

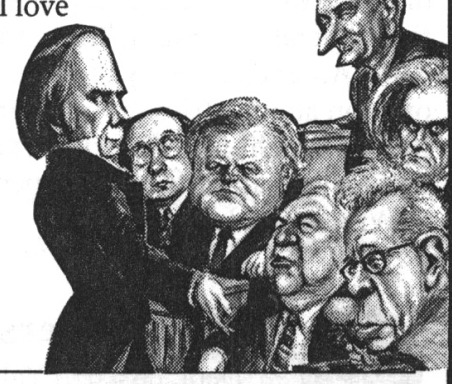




\section{Grand Strategies in War and Peace}

edited by Paul M. Kennedy

In this important book, the author of The Rise and Fall of the Great Powers brings together a group of distinguished authorities to look at how the United States, the Soviet Union, and various European powers have integrated their political, economic, and military goals in order to preserve their long-term interests in times of war and peace. The contributorsamong them Sir Michael Howard, J.H. Elliott, Douglas Porch, Condoleezza Rice, and Kennedy-provide insightful historical analyses and also offer incisive advice on the future directions nations should take. $\$ 25.00$

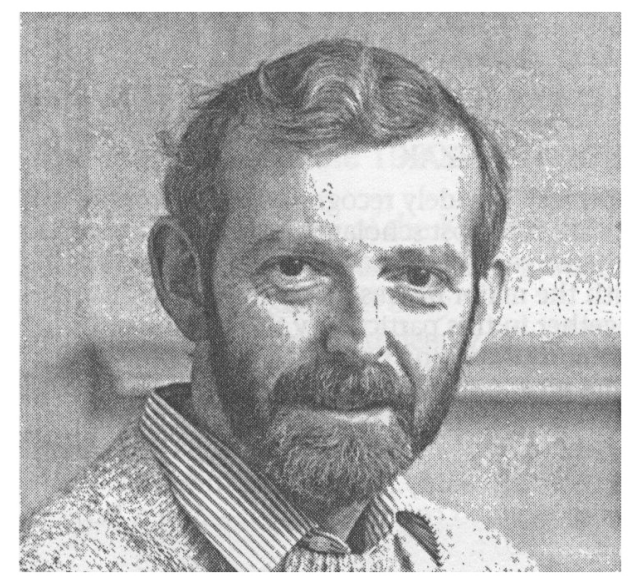

\section{American Intellectuals and African Nationalists, 1955-1970 \\ Martin Staniland}

"In this intellectually exuberant book, Martin Staniland systematically analyzes American reactions to Africa and manages to make sense of divergent and conflicting views of conservatives, liberals, Marxists, black Americans, white Americans, everyone who had an opinion about Africa. It is a work of originality and insight into the critical years of African nationalism and African independence."

-Wm. Roger Louis $\$ 30.00$

\section{Yale University Press}

Dept. 663, 92A Yale Station New Haven, CT 06520
Now available in paperback

\section{Democracy and Its Critics}

\section{Robert A. Dahl}

Winner of the American Political Science Association's Woodrow Wilson Foundation Book Award for 1990

"In this magisterial work (Dahl)...describe(s) what democracy means...; why our own democracy is still deeply flawed; and how we could reform it....A work of extraordinary intelligence and...wisdom."--Robert N. Bellah, The New York Times Book Review

"Dahl has produced a work destined to become another classic."-Lucian W. Pye, American Political Science Review $\$ 17.00$

\section{Germany, America, Europe} Forty Years of German Foreign Policy

\section{Wolfram F. Hanrieder}

"A major work on German policies....Rewarding."-Fritz Stern,Foreign Affairs

"Germany, America. Europe is not only the definitive account of its subject; it is also...a joy and a pleasure to read."-David Gress, The New York Times Book Review $\$ 18.00$

\section{Rebellion and Repression in the Philippines}

\section{Richard J. Kessler}

"Few students of the Philippines understand its problems as well as does Richard Kessler. His book is profound and perceptive, and deserves widespread attention."--Stanley Karnow $\$ 15.00$

\section{Seats and Votes}

\section{The Effects and Determinants of Electoral Systems}

\section{Rein Taagepera and Matthew Soberg Shugart}

"This book marks a considerable advance in our understanding of the complexities of electoral systems.... [It] will surely be studied by political scientists for many years to come."-Vernon Bogdanor, The Times Higher Education Supplement $\$ 16.00$ 


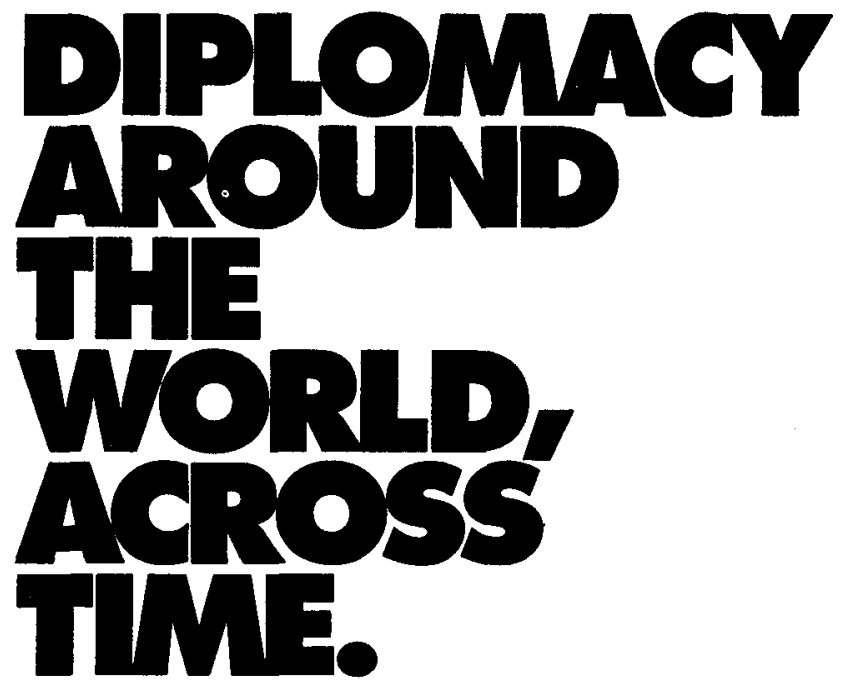

\section{HENRY KISSINGER \\ Doctor of Diplomacy}

Robert D. Schulzinger

Schulzinger presents a compelling look at one of the 20th century's most powerful and controversial shapers of U.S. foreign policy.

"This is the best study of Henry Kissinger to appear to date... wonderfully written, balanced, and judicious."

Stephen E. Ambrose, author of Eisenhower and Nixon Contemporary American History Series Now in paper! $\$ 13.95,304$ pp., photos

\section{CEORGE F. KENNAN}

Cold War iconclast

Walter L Hixson

"[Hixson's] view of Kennan as a forerumner of the current 'decline school'-in his concem about social health in America, about the environment, about military overstretch -is stimulating."

-The New Republic

Contemponary American History Series Now in paper! \$14.50, 38I pp.

\section{TRAPPED BY SUCCESS}

The Eisenhower

Administration and Vietnam

David L Anderson

Anderson provides the first systematic study of the diplomatic legacy left by the Eisenhower administration: how the administration committed itself and its successors to losing billions of dollars and thousands of lives in an effort to protect its own false and frail creation in Indochina. Contemporary American History Series

\section{POWER AND IEADERSHIP IN INIERATIONAL BARGANINC}

The Path to the Camp David Accords Shibley Telhami

In 1978, starting from seemingly irreconcilable positions, Egypt and Israel signed the Camp David Accords. Here, Telhami examines the accords, asking how these surprising agreements came to be, and how they fit in the scope of international relations and strategic conflicts. $\$ 40.00,280 \mathrm{pp}$.

\section{PROGRESS IN POSTWAR INIERNATIONAL RELATIONS}

Edited by Emanuel Adler and Beverly Crawford

Some of the most original thinkers in the field explore the occurrence and meaning of progress through international institutional change, interaction among states, policy, and changes in values, expectations, and attitudes.

The Political Economy of International Change $\$ 45.00,416 p p$ the formulation and implementation of
COMMAND IN CRISIS

Implications of

Stratified Crisis Intervention

Joseph F. Bouchard

Backed by recently declassified documents and interviews with crisis participants, Bouchard, a U.S. Navy surface warfare officer and strategic planning specialist, explores the problems that can arise when military force is used as a political tool in crises, and the implications of using this force for inadvertent escalation to war. $\$ 45.00,325 p p$.

\section{IENIN, TROTSKY AND STAIN}

The Intelligentsia and Power

\section{Philip Pomper}

Pomper examines the psychological and political dynamics of the three men who played key roles in shaping the Soviet Union. Delving into new information, as well as the insights of émigrés and dissidents, the author explores the relationship between the personal histories of these men and their political commitments. Now in paper! \$16.50, $464 \mathrm{pp}$.

\section{THE IMPACT OF CORBACHEV}

\section{Edited by Derek Spring}

Contributors examine Gorbachev's impact on domestic issues such as the nationalities debate, labor relations, and education, along with the creation of the Gorbachev image abroad, his strategy toward the United States, and his effect on

Eastem Europe as a whole.

$$
\text { 四 PINTER PUBLISHERS }
$$

Distributed in the U.S., Canada \& Latin America $\$ 49.00,256 p p$

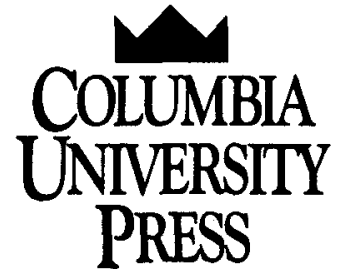

DEPT. 561 - 136 SOUTH BROADWAY IRVINGTON, NY IOS33

(914) 591-9111 FAX: (914) 591-9201

TO ORDER:

Send check/money order including $\$ 3.00$ for postage

Call or fax and use MC, VISA or AMEX. For CA delivery, add appropriote sales tax. 


\section{INTERNATIONAL DISPUTE SETTLEMENT}

\section{Second Edition}

\section{Professor J.G. Merrills}

A substantially expanded and updated edition of Professor Merrills' comprehensive survey of the methods and techniques employed in the peaceful settlement of international disputes. This book explains what the relevant techniques and institutions are, how they work and when they are used.

The new edition deals with many recent developments, discussing peace-keeping operations, current treaty practice, contemporary arbitral decisions, including the Rainbow Warrior case, and the latest case-law of the International Court of Justice.

$310 \mathrm{pp}$. including Index

Price: Paperback $₫ 19.50$ (US $\$ 39$ )

To be published July 1991

ISBN 0949009946

\section{COMPETITION POLICY AND MERGER CONTROL IN THE SINGLE EUROPEAN MARKET}

\section{The Rt Hon. Sir Leon Brittan, QC}

What is the jurisdictional basis for the operation of EC Competition rules? What is the scope and range of application of the recently adopted "Merger Regulation"? These questions are central to the administration of EC Competition policy and to any corporate strategic planning in Europe.

In two lectures delivered in February 1990 at the University of Cambridge, Sir Leon Brittan, who is the Vice-President of the European Commission, examines these problems in the context of the unfolding Single Market.

70 pp. including Index

Published June 1991

Price: Paperback $\& 15$ (US\$30)

ISBN $094900992 \mathrm{X}$

\section{INTERNATIONAL BOUNDARY CASES: THE CONTINENTAL SHELF}

With scores of continental shelf boundary problems still remaining to be settled, the convenience of having a handy, fully indexed collection of all the relevant international decisions is selfevident. Each case is preceded by a helpful summary. The collection has an Introduction by Michael Wallace.

Produced in a two volume casebound set

Volume I $883 \mathrm{pp}$. including Index

Volume II $827 \mathrm{pp}$. including Index

To be published Summer 1991

Price per set: $£ 120$ (US\$240)

ISBN 0949009849

Air Mail Postage $£ 8.00$ (US $\$ 15.00$ ) per volume.

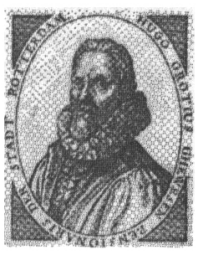




\section{Oklahoma Politics and Policies}

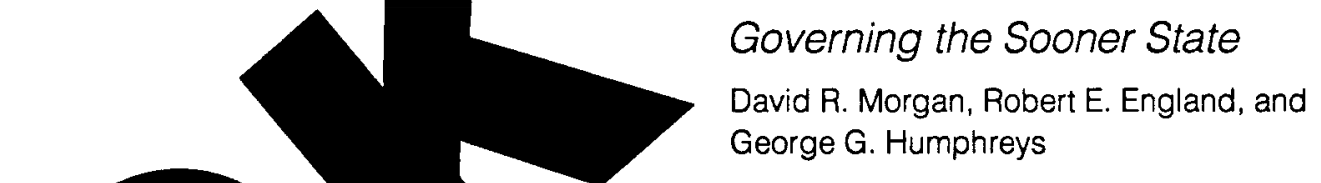

"A first-rate overview of Oklahoma politics.

Interesting, informative, and current, this work is a

superb contribution to the literature on state politics."

- Lelan McLemore, Carroll College. A volume in our

Politics and Governments of the American States series.

$\$ 14.95 \mathrm{pa}, \$ 35.00 \mathrm{cl}$

\section{Base Christian \\ Communities and Social Change in Brazil}

Available at bookstores or from

The University of Nebraska Press

$901 \mathrm{~N} 17$ th $\cdot$ Lincoln $68588 \cdot 0520$

(800) $755 \cdot 1105$

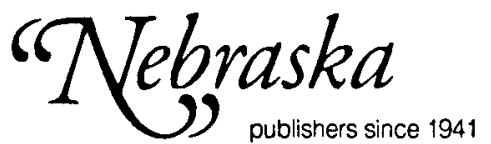

W. E. Hewitt

"A strong and valuable piece of scholarship. Hewitt's work is the most comprehensive and well-grounded of recent empirical efforts." - Daniel $\mathrm{H}$. Levine, author of Religion and Politics in Latin America. $\$ 24.95 \mathrm{cl}$
CONGRESSIOHAL CAREERS

Contours of life in the

U.S. House of Representatives

by John R. Hibbing

"A richly informative account. ... Fundamental to any serious discussion of the wisdom of term limits." - Gary C. Jocobson

opprox. 240 pp., \$29.95 cloth, \$12.95 poper

\section{RICHARD B. RUSSELL, JR., SENATOR FROM GEORGIA} by Gilbert C. Fite

"A compelling biography.... This is a major work, beautifully written, which should find a wide and enduring audience."

- Merle Black

584 pp. $\$ 29.95$

Fred W. Morrison Series in Southem Studies

\section{HUMAN RIGHTS TREATIES} AND THE SENATE

A History of Opposition

by Natalie Hevener Kaufman

"The definitive study of an episode in American public life as tawdry as it is drawn out."

-Nicholas Onuf

260 pp., $\$ 32.50$

\section{NEW WAYS AND MEANS}

Reform and Change in a

Congressional Committee

by Randall Strahan

"Essential reading for observers and scholars of Congress." -John F. Witte

238 pp., $\$ 29.95$ 


\section{The University of Alabama Press}

AIIS and the Public Work Force

Local Government Preparedness in Managing the Epidemic

James D. Slack

Slack surveyed 526 city managers and mayors across the U.S. during summer 1989, selecting local government as the focal point because it represents the largest work force in the nation. 200pp. \$17.95, paper

\section{The Disappearing South?}

Studies in Regional Change

and Continuity

Robert P. Steed, Laurence W. Moreland, and Tod A. Baker, editors

This volume does not purport to setle the debate on Southern political change, although it does present a variety of recent evidence that helps put this important debate into perspective.

328pp. \$31.95, cloth
Disability, Civil Rights, and Public Policy

The Politics of Implementation Stephen L. Percy

NAMED 1989 OUTSTANDING BOOK BYTHE Gustavus Myers Center for the Study of HuMan Rights IN the United States. Choick Outstanding AcaDEMIC BOOK FOR 1990-1991.

321pp. \$42.95, cloth

\section{The Christian Right and \\ Congress \\ Matthew C. Moen}

The Christian Rightand Congress chronicles the systematic attempts of conservative Christian interest groups to influence the Congress during the Reagan presidency.

245pp. \$32.95, cloth

\section{Corruption and Politics in Contemporary Mexico}

\section{Stephen D. Morris}

The author discusses scandals and gives examples of corruption for illustrative purposes, but his analysis is more theoretical than anecdotal. He questions whether in fact corruption has enhanced or diminished the stability of the Mexican government, and examines the reasons for the failure of many anti-corruption efforts.

192pp. \$18.95, paper

\section{INSTITUTE FOR SOCIAL SCIENCE RESEARCH MONOGRAPH SERIES}

Holding Bureaucrats

Accountable

Politicians and Professionals

in St. Louis

Lana Stein

160pp. \$19.95, paper

The Reach and Grasp

of Policy Analysis

Comparative Views of the Craft

Richard I. Hofferbert

205pp. \$19.95, paper
Political Voice

Citizen Demand for Urban

Public Services

Philip B. Coulter

112pp. \$14.95, paper

Child Abuse in the Deep South

Geographical Modifiers of Abuse Characteristics

Lee W. Badger, Nicholas A. Green, L. Ralph Jones, and Julia A. Hartman 260pp. \$18.95, paper

The University of Alabama Press • Box 870380 - Tuscaloosa, AL 35487-0380 


\section{New edition!}

World Resources 1992-93

WORLD RESOURCES INSTITUTE, Washington, D.C.

Praise for the previous edition: "Will provide an excellent springboard for quality discussions of currentenvironmental issues. Students can readily find data that would require endless hours to gather."-Darrell L. McDonald, Stephen F. Austin State University

The new edition includes a special focus on children's health, covering major causes of mortality, new initiatives to improve child survival, the role of nutrition in child health and survival, and issues in financing child health care. Other chapters cover environmental decline in Eastern Europe, sustainable agriculture in the developed world, forests and rangelands, energy and wastes, freshwater, oceans and coasts, and atmosphere and climate conditions and trends. January 1992384 pp.; illus. paper $\$ 15.95$ cloth $\$ 29.95$

\section{New! \\ Philosophy, Politics, Autonomy}

Essays in Political Philosophy

CORNELIUS CASTORIADIS, Ecole des Hautes Etudes

en Sciences Sociales

Edited by DAVID AMES CURTIS

Discussing Plato, Aristotle, Leibniz, Kant, Hegel, Weber, Heidegger, and Habermas, these remarkable essays include Castoriadis's latest contributions to philosophy, political and social theory, classical studies, development theory, cultural criticism, science, and ecology.

1991320 pp. paper $\$ 14.95$ cloth $\$ 35.00$

\section{The Theoretical}

\section{Evolution of International Political Economy}

\section{A Reader}

Edited by GEORGE T. CRANE, Williams College, and

ABLA M. AMAWI, Georgetown University

This collection of eighteen seminal readings in intemational political economy includes works by Alexander Hamilton, Friedrich List, David Ricardo, Adam Smith, Lenin, Karl Marx, Richard Cooper, Robert O. Keohane, Joseph S. Nye, Theotonio Dos Santos, Christopher ChaseDunn, Robert Gilpin, Peter Katzenstein, Mancur Olson, Richard Zeckhauser, Bruon Frey, Immanuel Wallerstein, Donald J. Puchala, Raymond F. Hopkins, and Stephen Krasner.

1991320 pp.; 5 illus. paper $\$ 18.95$

\section{New! Lessons of Struggle South African Internal Opposition, 1960-1990 \\ ANTHONY W. MARX, Columbia University}

An in-depth analysis of thirty years of South African opposition, this unique new text focuses on the development of the ideas and organizations of the Black Consciousness movement founded by Steve Biko, the ANC-aligned United Democratic Front, and the burgeoning trade unions. November $1991352 \mathrm{pp}$.; 13 illus. paper $\$ 15.95$ cloth $\$ 42.50$

\section{The Apartheid State in Crisis}

Political Transformation of South Africa, 1975-1990

ROBERT M. PRICE, University of California, Berkeley

"Very impressive....Comes near to being 'the one book you should read if you want to understand South Africa today."'-Gail Gerhart, Columbia University

1991328 pp.; 28 illus. paper $\$ 16.95$ cloth $\$ 55.00$

\section{Mandela, Tambo, and the African National Congress} The Struggle Against Apartheid, 7948 $1990, A$ Documentary Survey Edited by SHERIDAN JOHNS, Duke University, and R. HUNT DAVIS, Jr., University of Florida "A wonderful collection....of speeches, texts, documents, and testimonials. A must for anybody interested in the African National Congress and the struggle for equality and justice in Africa."-Nadar Entessar, Spring Hill College 1991376 pp.; 2 illus. paper $\$ 13.95$ cloth $\$ 35.00$

\section{Women and Social Protest}

Edited by GUIDA WEST, Federation of Protestant Welfare Agencies, New York, and RHODA LOIS BLUMBERG, Rutgers University

"An interesting collection....Should provide a springboard for lively classroom discussion."-Robert W. Langran, Villanova University

$1990416 \mathrm{pp}$. paper $\$ 18.95$ cloth $\$ 29.95$

Prices and publication dates are subject to change.

To request an examination copy, write on school letterhead giving full course information, including

course name, level, expected enrollment, and your decision deadline, to:

\section{Oxford University Press}

ATTN: College Sales Coordinator 


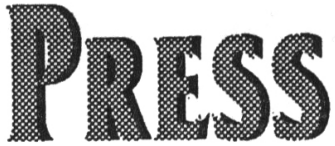

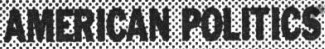

\section{NEW}

\section{THE GOVERNING CRISIS}

Media, Money, and Marketing in American Elections W. LANCE BENNETT, University of Washington

Arguing that our political system selects candidates who are better at running for office than they are at governing, W. Lance Bennett examines two urgent problems in American politics: the declining quality of political debate in American elections and the inability of elected officials to make effective public policy. Drawing on his comprehensive research, as well as his insider connections with popular journalists and politicians, Bennett provides valuable insight into the roles of money, marketing, and the media in American elections.

Paperbound. 288 pp. (probable)

Publication: November 1991

Prepublication examination coples now available

\section{NEW \\ POINT-COUNTERPOINT}

Readings in American Government

Fourth Edition

HERBERT M. LEVINE

The fourth edition of Point-Counterpoint offers 21 sets of pro/con readings on important - and controversial - issues in American government. The readings strike a balance between traditional and more contemporary concerns, and all were chosen to promote active classroom discussion.

Paperbound. 356 pp.

Publication: November 1991

Prepublication examination coples now available

\section{NEW}

\section{THE POSTREFORM CONGRESS}

ROGER H. DAVIDSON, University of Maryland, College Park

The Postreform Congress comprises 15 original essays that address different aspects of contemporary legislative politics. Commissioned and written specifically for astudent audience, the essays are all the work of noted scholars in the field. Among the contributors are policy analysts, presidential and parties scholars, formal theorists, and voting analysts.

Paperbound. 384 pp. (probable)

Publication: November 1991

Prepublication examination copies now available

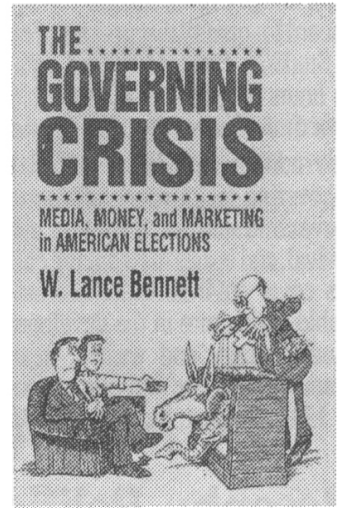




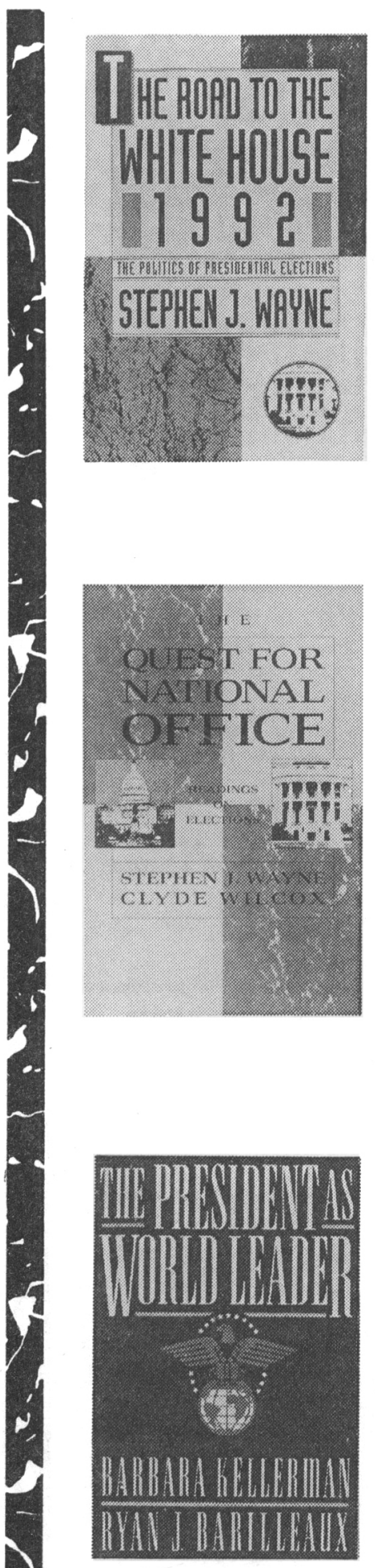

NEW

THEROAD TO THE WHITE HOUSE, 1992

The Politics of Presidential Elections

STEPHEN J. WAYNE, Georgetown University

Written by one of America's most distinguished scholars on the presidency, The Road to the White House provides a concise yet complete account of the politics of presidential elections. This edition has been completely updated with the new Electoral College figures (1990 census), complete revenue and spending figures for the 1988 election, new polls on party coalitions, and final election returns for 1988 .

Paperbound. 336 pp. (probable)

Publication: November 1991

Prepublication examination copies now available

\section{NEW}

\section{THE QUEST FOR NATIONAL OFFICE}

Readings on Elections

STEVEN J. WAYNE and CLYDE WILCOX, both of Georgetown University

A collection of 52 readings that introduce students to the environment in which congressional and presidential elections occur, their rules and procedures, the strategy and tactics of nominations, the general election, and the meaning of the election and its impact on government. Scholarly essays alternate with popular journalistic pieces for balanced coverage of the electoral process.

Paperbound. 352 pp. (probable)

Publication: November 1991

Prepublication examination coples now avallable

TIERMTTONA RELATONS C TORIGN POLIOU

\section{THE PRESIDENT AS WORLD LEADER}

BARBARA KELLERMAN, George Washington University and Fairleigh Dickinson University

RYAN J. BARILLEAUX, Miami University

An evaluation of the presidency that focuses on the president as the national leader in the formulation of foreign policy, and the president as the key representative of American interests in the international environment. Case studies of five recent presidents examine their leadership abilities both at home and abroad with regard to some of the major foreign policy initiatives of their administrations.

Paperbound. 225 pp. 1991

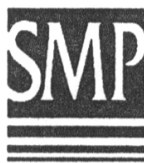

\section{ST. MARTIN'S PRESS}

College Division, Department JR

175 Fifth Avenue, New York, N.Y. 10010

College Desk 1-800-446-8923 


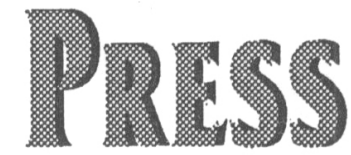

\section{NATIONAL SECURITY}

Enduring Problems in a Changing Defense Environment Second Edition

DONALD M. SNOW, University of Alabama

A brief overview that explains how defense issues and instruments of national power work as components in the formulation of U.S. national security policy. The second edition covers the recent changes in the international environment, strategic use of conventional and nuclear arms, and economic issues as they relate to defense policy and national strength. Included is a new chapter on the decision making process in national security policy.

Paperbound. 320 pp. 1991

\section{RECONSTRUCTING CONSENSUS}

American Foreign Policy since the Vietnam War

RICHARD A. MELANSON, Brown University, Kenyon College

Reconstructing Consensus examines the reformulation of American foreign policy in the aftermath of the war in Vietnam. Organized by presidential administrations from Richard Nixon to George Bush, the book traces attempts to forge a new foreign policy consensus to replace what had been severely challenged by the American experience in Vietnam.

Paperbound. 248 pp. 1991

\section{WORLD SECURITY}

Trends and Challenges at Century's End MICHAEL T. KLARE, Hampshire College DANIEL C. THOMAS, Cornell University

World Security presents 17 original contributions (and one previously published article) from leading writers in international relations and peace studies. It is the first text or reader to present major issues in international politics from a consistent, globalist framework. The book's broad definition of world security includes a range of nonmilitary issues - human rights, famine, debt and development, and global ecology.
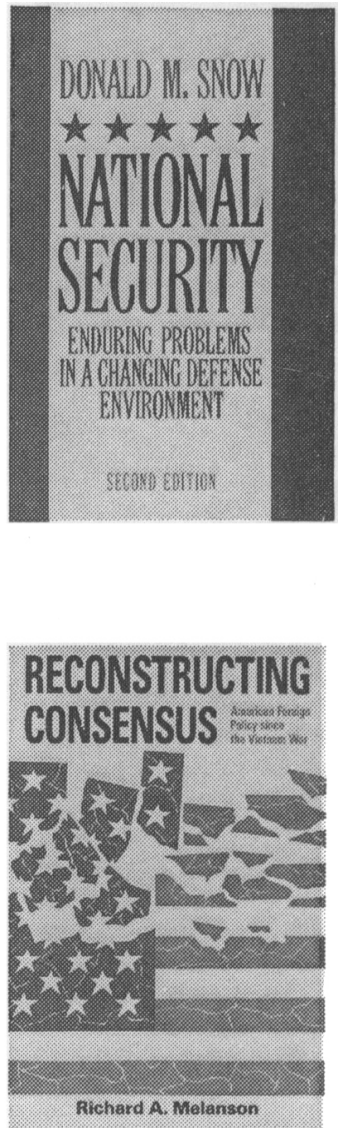

Paperbound. 448 pp. 1991

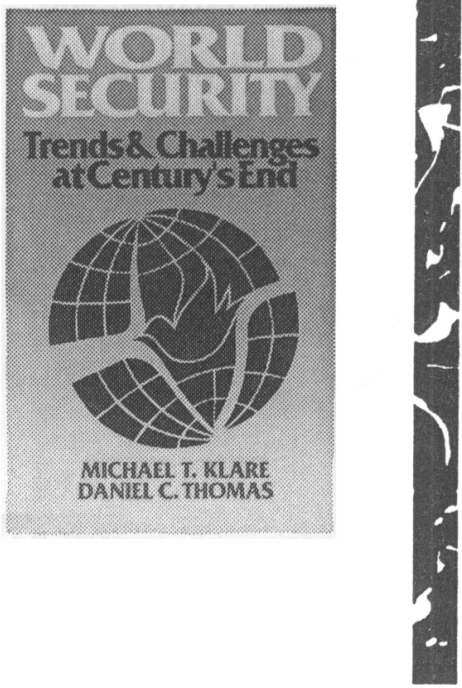




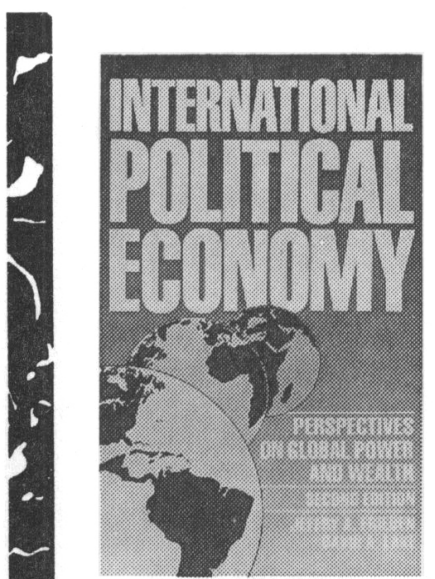

\section{INTERNATIONAL POLITICAL ECONOMY}

Perspectives on Global Power and Wealth

Second Edition

JEFFRY A. FRIEDEN, and DAVID A. LAKE, both of the

University of California, Los Angeles

Retaining its consistent, critical focus on theory and analysis, the second edition of International Political Economy offers contemporary articles on a wide range of issues including multinational corporations, foreign investment, trade imbalances, and the fluctuating value of the dollar.

Paperbound. 470 pp. 1991

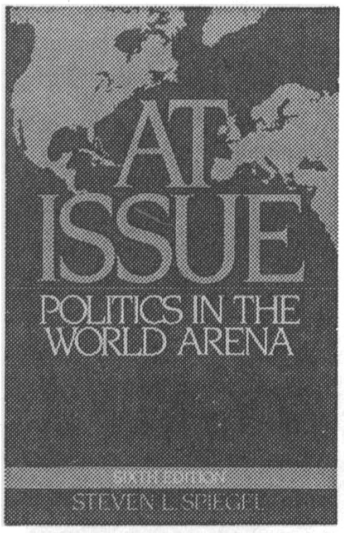

\section{AT ISSUE}

Politics in the World Arena

Sixth Edition

STEVEN L. SPIEGEL, University of Los Angeles, California

An authoritative collection of 34 contemporary readings (all of which are new to this edition) by leading theorists and writers who deal with the most immediate issues in world politics today. The new edition includes selections on changes in superpower relations, the Pacific Rim economy, and the international drug war, and also provides expanded coverage of the environment and global ecology as a security issue.

Paperbound. 518 pp. 1991

\section{AMERICAN FOREIGN POLICY}

Pattern and Process

Fourth Edition

CHARLES W. KEGLEY, JR., University of South Carolina EUGENE R. WITTKOPF, Louisiana State University

A thorough introduction to the process and objectives of postwar American foreign policy. New to the fourth edition are expanded treatment of the Gorbachev era reforms and updated material on the international political economy and its implications for U.S. foreign policy.

Paperbound. 656 pp. 1991

\section{ST. MARTIN'S PRESS}

College Division, Department JR

175 Fifth Avenue, New York, N.Y. 10010

College Desk 1-800-446-8923 
NEW

THE FUTURE OF AMERICAN FOREIGN POLICY

CHARLES W. KEGLEY, JR., University of South Carolina EUGENE R. WITTKOPF, Louisiana State University

The Future of American Foreign Policy brings together 28 essays - two of them written specifically for this volume - that explore the major questions confronting American foreign policy makers in the wake of the Cold War. The essays, all written by prominent policy makers and academic specialists, represent a wide range of viewpoints and perspectives on different options, priorities, and directions the U.S. must consider in formulating a foreign policy for the 1990s and beyond.

Paperbound. 336 pp. (probable)

Publication: November 1991

Prepublication examination coples now available

\section{NEW}

\section{SOVIET POLITICS}

Struggling with Change

Second Edition

GORDON B. SMITH, University of South Carolina

In this second edition, Gordon Smith provides a concise, fully up to date study of the Soviet political system. $\mathrm{He}$ covers all the recent fundamental changes in the conduct and structure of the Soviet government and goes beyond describing political institutions to explore a wide range of influences on the system, including history, culture, religion, ideology, and technology.

Paperbound. 400 pp. (probable)

Publication: November 1991

\section{COMPARA TIUL POLIILS}

\section{NATIONS AND GOVERNMENTS}

Comparative Politics in Regional Perspective

THOMAS M. MAGSTADT, Air War College

Nations and Governments provides a contempo-

rary global context to help students compare the political settings, institutions, and trends in six world regions: Western Europe, the Soviet Union and Eastern Europe, the Middle East, Asia, Sub-Saharan Africa, and Latin America. Key nations in each region are highlighted as case studies to show how they exemplify or diverge from the region's characteristics. Includes coverage of the recent realignments in Europe and the Soviet bloc.

Hardcover. 544 pp. 1991

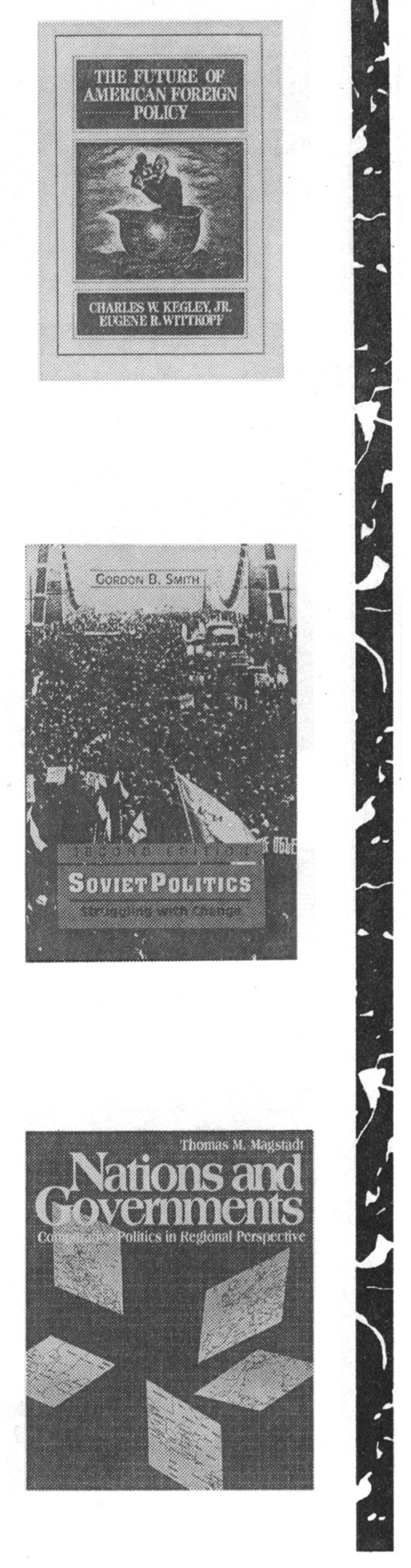




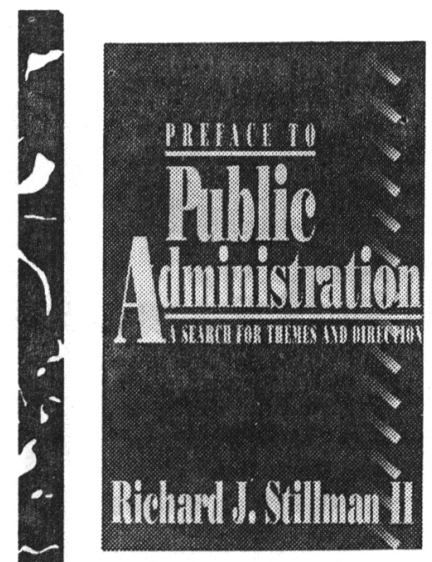

PUBMIC ADMIISTRATION

\section{PREFACE TO PUBLICADMINISTRATION}

A Search for Themes and Direction

RICHARD J. STILLMAN II, George Mason University

Preface to Public Administration is a thoughtful

consideration of the development of the theory and practice of public administration in America. The author examines the development of public administration from the late 18th century on, and contrasts the history of public administration in the U.S. with that of the public administration in Europe.

Paperbound. 242 pp. 1991

\section{NEW \\ PUBLIC ADMINISTRATION IN AMERICA} Fourth Edition

\section{GEORGE J. GORDON}

Like its highly successful predecessors, this fourth edition of Public Administration in America provides a balanced, comprehensive, highly readable introduction to the field. Professor Gordon fully integrates both political and managerial perspectives on public administration, and he considers the future of public administration and its role in a democratic government - specifically, how government influences, and is influenced by, a complex bureaucracy of nonelected public officials.

Hardbound. 608 pp. (probable)

Publication: November 1991

Instructor's Manual available

\section{MIGA. TIEOAY}

\section{NEW \\ POLITICAL THEORY}

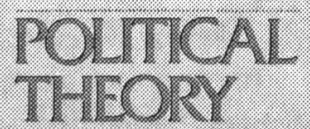

Classic Writings: Contemporary Views

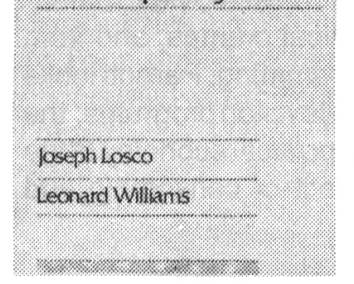

Classic Writings, Contemporary Views JOSEPH LOSCO, Ball State University LEONARD WILLIAMS, Manchester College

A comprehensive, one-volume history of Western political thought, Political Theory introduces students to 16 major thinkers, from the ancient Greeks to the present. The writings of each philosopher are paired with two contemporary commentaries, chosen for their accessibility, their ability to provide students with contrasting views on each thinker, and their demonstration of the relevance of the writings in contemporary times.

Hardbound. 736 pp. (probable)

Publication: November 1991

Prepublication examination coples now available 


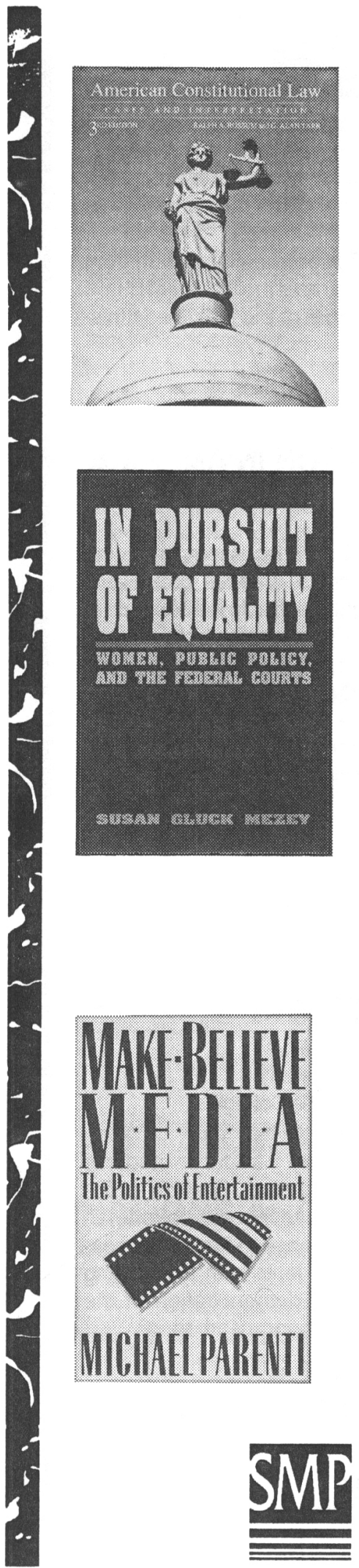

\section{AMERICAN CONSTITUTIONAL LAW}

Cases and Interpretation

Third Edition

RALPH A. ROSSUM, Claremont McKenna College

G. ALAN TARR, Rutgers University, Camden Campus

A topically organized text for the American constitutional law course that focuses on constitutional interpretation. This edition is updated with constitutionally significant pronouncements of Congress since 1987. Accompanied by an annual supplement that summarizes important cases from recent Supreme Court sessions.

Hardcover. 768 pp. 1991

\section{NEW \\ IN PURSUIT OF EQUALITY}

Women, Public Policy, and the Federal Courts

SUSAN GLUCK MEZEY, Loyola University of Chicago

In Pursuit of Equality traces the development of women's equality under federal law from 1960 to the present and examines the effectiveness of the federal courts in implementing expanded legal rights and protections for women. Includes a consideration of the actions of Congress and the executive branch in determining the scope of women's rights in America.

Paperbound. 304 pp. (probable)

Prepublication examination coples now available

\section{W33A}

\section{NEW}

\section{MAKE-BELIEVE MEDIA}

The Politics of Entertainment MICHAEL PARENTI

In Make-believe Media, Michael Parenti examines film and television from a political perspective. Drawing his exam ples from Westerns, monster movies, romantic comedies, family sitcoms, medical dramas, and from cartoons and other children's programming, Parenti looks at the content of popular films and television programs; the effects of the media on society; the political economy of the entertainment industry; and the fact of censorship and control within the industry.

Paperbound. 304 pp. (probable)

Publication: November 1991

Prepublication examination copies now available

\section{ST. MARTIN'S PRESS}

College Division, Department JR

175 Fifth Avenue, New York, N.Y. 10010

College Desk 1-800-446-8923 


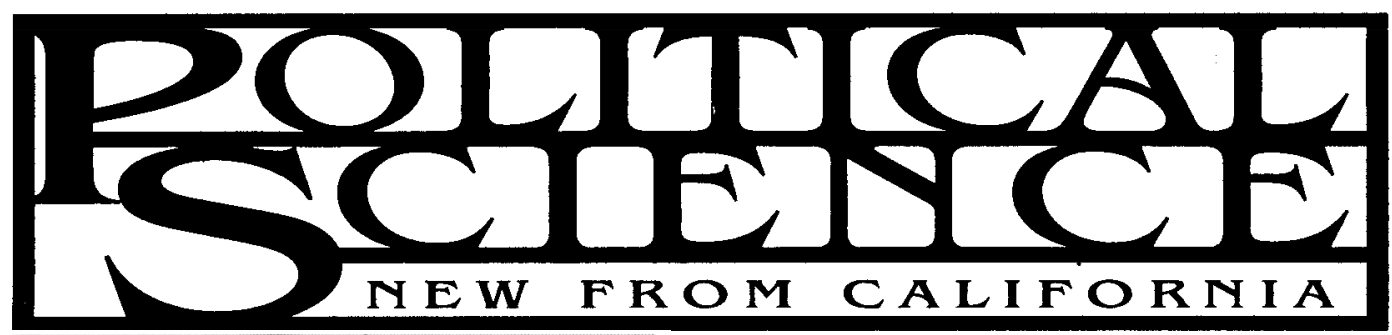

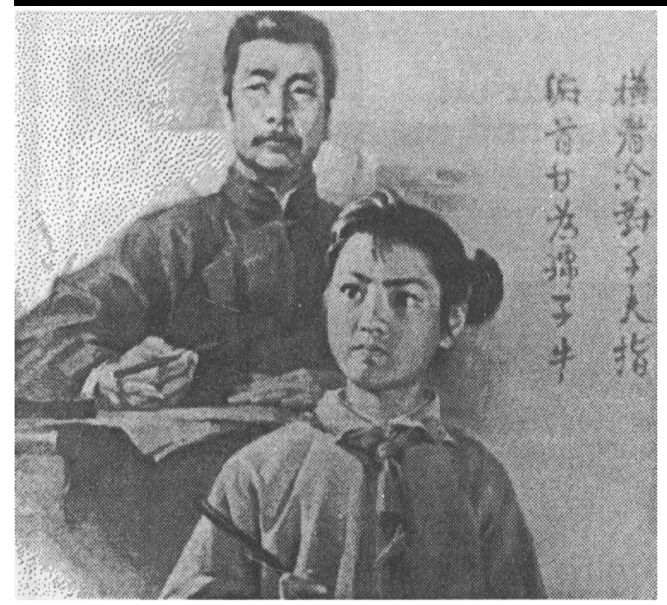

\section{War and Secession}

Pakistan, India, and the Creation of Bangladesh

\section{RICHARD SISSON and LEO ROSE}

New in paper -"A remarkable book ... It combines academic scholarship with the skills of a novelist weaving together a thriller. ... This is easily one of the better and more balanced books to have appeared on the subject in recent years." $\$ 13.95$ paper, 350 pages

-American Political Science Review

\section{Palestine and Israel}

The Uprising and Beyond

DAVID MCDOWALL

New in paper-"McDowall has established himself as the most authoritative guide to the maze of Israeli-Palestine politics. His timely and important book should be required reading for everyone concerned with this conflictand certainly in every Israeli household."-The Observer $\$ 13.95$ paper, 335 pages

\section{Brushes with Power}

Modern Politics and the Chinese Art of

Calligraphy

\section{RICHARD CURT KRAUS}

"In Kraus's hands, thestudy of calligraphy becomes a metaphorforamuch widertopic-thepersistence of traditionalism in modern China."

-Richard Madsen, author of Morality and Power in a Chinese Village $\$ 24.95$ cloth, 224 pages, illustrated

\section{Anarchism in the Chinese Revolution}

\section{ARIF DIRLIK}

Dirlik offers a revisionist perspective on Chinese radicalism in the 20th century arguing that the history of anarchism is key to understanding crucial themes in Chinese radicalism.

$\$ 39.95$ cloth, 336 pages

\section{State and Peasant in Contemporary China}

The Political Economy of Village

Government

JEAN C. OI

New in paper-"Oi contributes more to our understanding of the last few decades of China's politics and of state-peasant relations generally than a six-foot shelf of social science theory."

-James C. Scott, Yale University $\$ 13.95$ paper, 308 pages, illustrated

At bookstores or order toll-free 1-800-822-6657. Visa $\mathbb{E}$ MasterCard only.

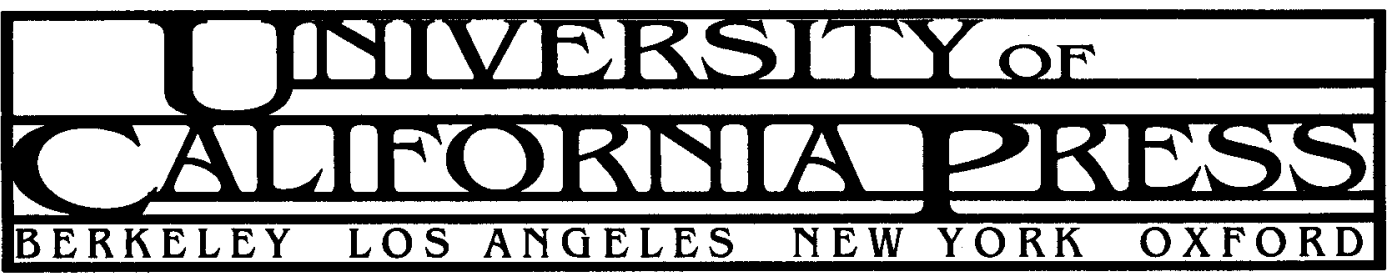




\section{Westview}

Popular Protest and

Political Culture in

Modern China

Learning from 1989

edited by Jeffrey $\mathbf{N}$. Wasserstrom

and Elizabeth J. Perry

November $1991 \bullet$ ca. 256 pp. $\bullet \$ 49.50$ hc •

$\$ 19.50 \mathrm{pb}$

The Battle

for

Guatemala

Rebels, Death

Squads, and

U.S. Power

Susanne Jonas

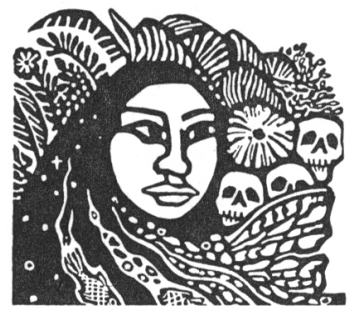

Art by Rini Templeton

August 1991 • Courtesy of The Real Comet Press ca. 252 pp. $\$ 40$ hc $\$ 16.95$ pb

\section{Virtues and Rights}

The Moral Philosophy of

Thomas Hobbes

R.E. Ewin

August $1991 \bullet$ ca. 208 pp. $\bullet \$ 38.50$ hc

\section{The Diplomatic Record,} 1990-1991

edited by David D. Newsom

"A valuable and unique reference and research tool ... and a welcome addition to the growing literature on diplomacy and negotiation." -Library Journal

December $1991 \bullet$ ca. 300 pp. $\bullet \$ 49.95$ hc

\section{Political Cultures} Series

\section{A Genealogy of} Political Culture Michael Brint

"A tour de force of liberal education, scholarship that is learned, lucid, and engaged." -Robert L. Payton, Indiana University

September $1991 \bullet$ ca. 192 pp. $\bullet \$ 29.95$ sc
Law and Force in the New International Order edited by Lori Fisler Damrosch and David J. Scheffer

August $1991 \bullet$ ca. 325 pp. $\bullet \$ 45$ hc $\bullet \$ 19.95$ pb

The War on

Labor and the Left

Understanding

America's Unique

Conservatism

Patricia Cayo

Sexton

October $1991 \bullet$

ca. 330 pp. $\bullet \$ 24.95$ hc

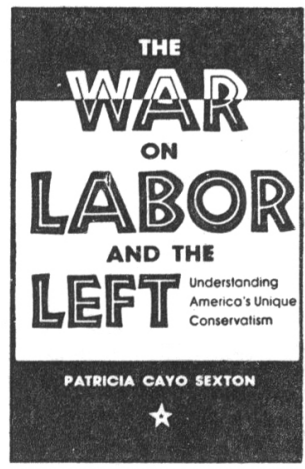

Feminist Legal Theory

Readings in Law and Gender edited by Katharine T. Bartlett and Rosanne Kennedy

November $1991 \bullet$ ca. 383 pp. $\bullet \$ 55$ hc $\bullet$ $\$ 16.95 \mathrm{pb}$

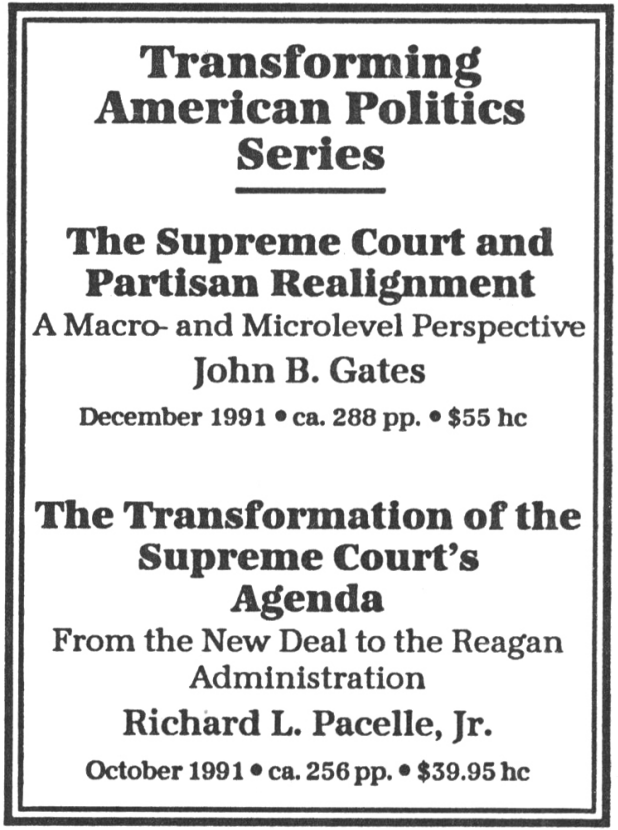




\section{Postdoctoral Fellowship for Research in International Security Studies.}

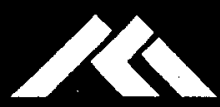

The Mershon Center is seeking applicants for postdoctoral research in international security affairs. Possible areas of interest include:

- U.S. defense and foreign policy

- international conflict resolution

- military history

- civil-military relations

Preference will be given to applicants with a solid design for completing a book-length manuscript during the fellowship year. The appointment will be for up to twelve months beginning July 1 , 1992. The stipend will be at approximately $\$ 29,000$ per annum. Only persons holding a doctorate awarded since June 1987 are eligible to apply.

If interested, request an application package from:

Fellowship Coordinator

Mershon Center

The Ohio State University

199 West Tenth Avenue

Columbus, $\mathrm{OH}$ 43201-2399

(614) 292-1681

Applications due November 15, 1991

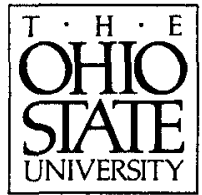

ב

American Government

POINTSOF VIEW, $5 / \mathrm{e}$

DiClerico/Hammock

POLITICS AND THE AMERICAN

FUTURE, $3 / \mathrm{e}$

Harrigan

AMERICAN GOVENMENT: The Core, 2/e

Woll/Zimmerman

National Security

THE POLITICAL ECONOMY OFNATIONAL SECURITY

Kapstein

International Relations

THE GLOBAL AGENDA, 2/e

Kegley/Wittkopf

WORLD POLITICS DEBATED, 4/e

Levine

INTERNATIONAL RELATIONS, $3 / \mathrm{e}$

Pearson/Rochester
Constitutional Law

THE SUPREME COURT AND THE CONSTITUTION

Steamer/Maiman

Comparative European Government

REPRESENTATIVE GOVERNMENT IN

WESTERN EUROPE

Gallagher/Laver/Mair

Political Economy

THE POLITICAL ECONOMY OF

DEVELOPMENT AND

UNDERDEVELOPMENT, $5 / \mathrm{e}$

Wilber/Jameson

For more information, please contact your local MoGraw-Hill representative or write: McGrawHill College Division, Comp Processing and Control, P.O. Box 448, Hightstown, NJ 08520.

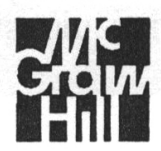




\section{H. B. Paksoy \\ ALPAMYSH: CENTRAL ASIAN IDENTITY UNDER RUSSIAN RULE \\ (Hartford, CT: Association for the Advancement of Central Asian Research) \\ (Paperback) \$10.95; (Hardcover) \$49.95 + \$2.50 S \& H \\ Prepayment required from individual purchasers}

ORDERS: Treasurer, AACAR, Department of History, UMASS-Amherst, MA 01003

Paksoy... is absolutely right about the value of the oral, "folk" records like the dastans for preserving ethnic identity... I am also impressed by Paksoy's insistence (contra a rash of superficial contentions recently) that a fundamental unity of Turks persists across all artificial Soviet divisions...

John A. Armstrong - Emeritus, University of Wisconsin-Madison

Through his scholarly commentary on this important epic of the Turkic peoples of Central Asia, Paksoy conveys an understanding of its political as well as its cultural significance for the relationship between the Turkic peoples and the Russian or Soviet state.

\section{Ralph T. Fisher - University of Illinois, Urbana-Champaign}

Epic and politics -- yes, always!

\section{Arthur T. Hatto - University of London}

I have only the highest praise for its scholarship. It... [is] an illuminating case study of the importance of the collective memory for the maintenance of ethnic and community identity.

\section{Keith Hitchins - University of Illinois, Urbana-Champaign}

H. B. Paksoy masterly reconstitutes the shabby saga of Tsarist/Soviet efforts first to muzzle this authentic vox populi and then to pervert the message of these texts...

Guy Imart - Universite De Provence, Aix Marseille I

Dr. Paksoy has with the publication of his book rendered a great service... to all those scholars who devote their time to research in Soviet inter-ethic relations....

Ambassador Gunnar Jarring - Sweden

Dr. Paksoy opened a new stage in Central Asian area studies. The fresh fruits of [his] thorough investigation on Soviet Central Asian literature, history and politics are integrated in this work...

$$
\text { Hisao Komatsu - School of Letters, Tokai University }
$$

Dr. Paksoy's absorbing book contains... a concise account of Soviet language policy...

$$
\text { Geoffrey L. Lewis - Oxford University }
$$

This is one of those rare books which offer the Western reader a Central Asian perspective on the Russian conquest of the non-Slavic territories in Asia.

Ewa M. Thompson - Rice University

Dr. Paksoy has done a beautiful job with the dastan Alpamysh. The work is meticulously and exactingly done, and presented clearly.

Wayne S. Vucinich - Stanford University 


\section{Global Impact of Economic and Political}

\section{Reforms in Eastem Europe and the USSR}

\section{Economic Bulletin for Europe}

This is the latest review of economic developments in Europe and North America, with special emphasis on Eastern Europe and the Soviet Union. It describes the process of transforming centrally planned economies into decentralized market economies as well as a detailed analysis of the oil shocks emanating from the Gulf and another shock due in 1991 when the USSR begins to charge world prices in convertible currency for its oil exports to Eastem Europe. 120 pp.

E.90.II.E.37 92-1-116493-1 $\$ 55.00$

\section{Economic Survey of Europe in 1990-1991}

This publication provides an account of the principal macro-economic developments in the European region. It offers a framework for viewing the reform process in Eastem Europe and in Europe as a whole, and analyses the optimal framework for the western support to economic reforms in eastern countries, with particular emphasis on the relevance of the MARSHALL PLAN. The Survey includes statistical appendices and $a$ list of over fifty tables and charts quantifying the evaluation. $255 \mathrm{pp}$.

\section{E.91.II.E.1 92-1-116508-3 $\$ 80.00$}

\section{Reforms in Foreign Economic Relations of Eastern Europe and the Sovlet Unlon} This publication features each country's institutional framework including data on foreign trade payments; decentralization of decision-making; exchange rate system; export and import policies; joint ventures; and impact of reforms in the external sector on the country's participation in the international trade. Also presented are the economic relations of each country with market economies and with socialist countries. $202 \mathrm{pp}$. E.91.II.E.5 $92-1-116502-4 \quad \$ 60.00$
The Challenge of Free Economic Zones In Central and Eastern Europe: International Perspectlves

In the last few years, China and a number of Central and Eastem European countries have set up free economic zones whose immediate objective is to attract foreign direct investment to assist in international economic restructuring. This study examines all major aspects linked to the establishment of free economic zones in Eastem Europe and the USSR. It discusses the role and objectives of free economic zones in economic development and points out relevant lessons from other countries. For both investors and policy makers, this important study will give them a better understanding of the rewards and challenges of free economic zones as they open up in Eastern Europe. 460 pp.

\section{E.90.II.A.27 92-1-104358-1 $\$ 75.00$}

\section{East-West Joint Venture Contracts}

Reprinted due to popular demand, this book reflects practical experiences from joint ventures in the Soviet Union, Romania, Poland, Hungary, Czechoslovakia and Bulgaria. Model joint venture contracts and charters are also included. 224 pp.

E.88.II.E.30 92-1-164370 $\$ 50.00$

\section{FREE}

United Nations Publications Catalogue 1990-91 Update

If you have not yet received your 1990-91 UN Publications Catalogue, order your FREE copy now. The new format is arranged by topic ranging from Demographic, Economic, Finance, Environment, Human Rights, Int'1 Law, Business, Peace, Security, Public Administration, Science, Technology and Social Questions.

\section{Send orders to:}

United Nations Publications, Sales Section, Room DC2-0853 Dept. 720

New York, N.Y. 10017 Tel. (800) 553-3210, (212) 963-8302, Fax (212) 963-3489.

Visa, MasterCard and American Express orders accepted for orders over $\$ 15.00$.

Please add 5\% to gross amount, $\$ 3.50$ minimum for shipping \& handling. 


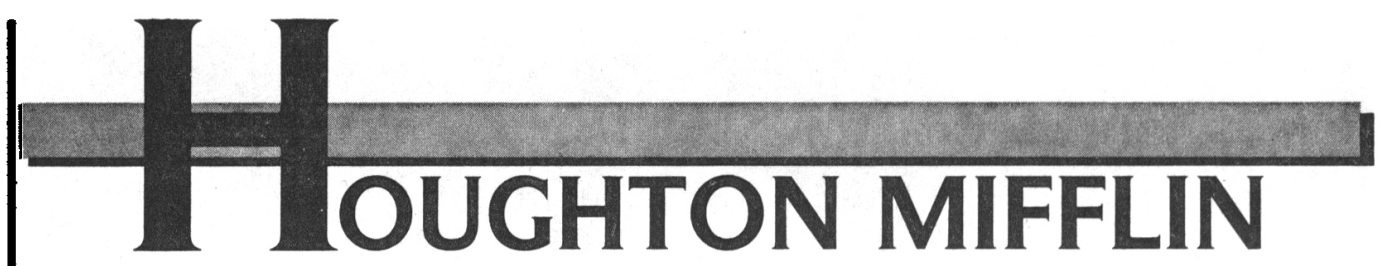

$\mathbf{W}_{\text {ith each new year, Houghton }}$ Mifflin renews and builds on its commitment to excellence.

You've watched our list grow from a select few to an impressive array of titles, with each new book answering an emerging need in the political science curriculum. And your demands for carefully written and developed textbooks have always been satisfied.

For 1992, Houghton Mifflin offers only the finest learning materials from some of the best names in the field: Janda/Berry/Goldman's everpopular The Challenge of Democracy. Cigler/Loomis's American Politics, Ray's Global Politics, Stillman's Public Administration, and Jones et al.'s Practicing Texas Politics.

In the coming years you can expect continued excellence from us as our political science list builds into the future. 


\section{BUILDING ON EXCELLENCE FOR 1992}

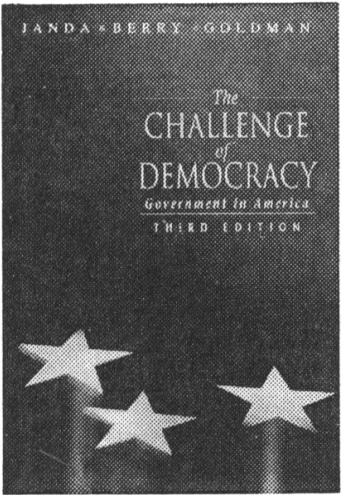

AMERICAN GOVERNMENT

The Challenge of Democracy: Government in America, Third Edition

Kenneth Janda

Northwestern University

Jeffrey M. Berry, Tufts University

Jerry Goldman

Northwestern University

832 pages - hardcover - Complete support package $\bullet$ Fall 1991

\section{American Politics:}

Classic $\bar{\alpha}$ Contemporary Readings, Second Edition

Allan J. Cigler

Burdett A. Loomis

Both of University of Kansas

688 pages $\bullet$ paperback $\bullet$ Instructor's

Resource Manual • Fall 1991
GLOBAL POLITICS

Global Politics, Fifth Edition

James Lee Ray

Florida State University

580 pages - paperback $\cdot$ Complete

support package • Fall 1991

\section{PUBLIC ADMINISTRATION}

Public Administration:

Concepts and Cases Fifth Edition

Richard J. Stillman II

George Mason University

528 pages • paperback • Instructor's

Resource Manual • Fall 1991

\section{TEXAS POLITICS}

\section{Practicing Texas Politics} Eighth Edition

Eugene W. Jones

Angelo State University

Joe E. Ericson

Stephen F. Austin State University

Lyle C. Brown, Baylor University

Robert S. Trotter, Jr., El Centro

College of the Dallas County

Community College System

506 pages - paperback - Complete

support package • Fall 1991

For adoption consideration, request examination packages from your Houghton Mifflin regional office.

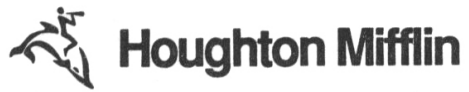




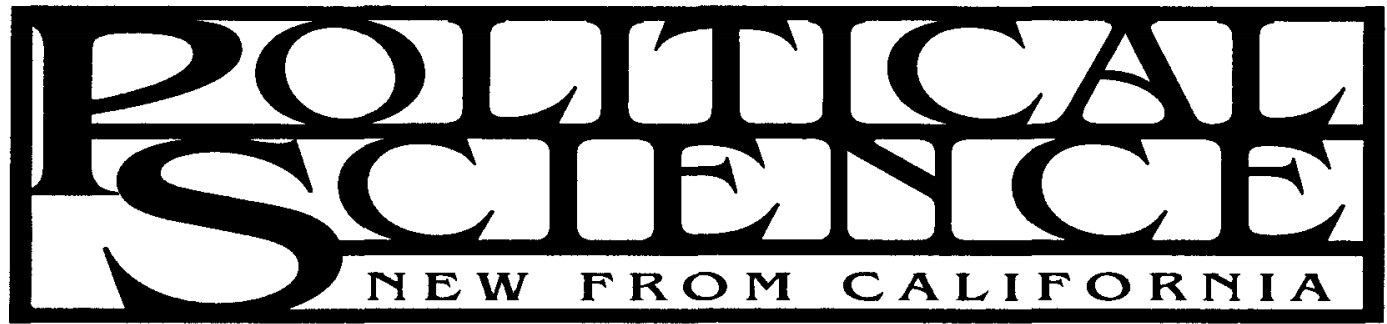

\section{Toil and Toxics}

Workplace Struggles and Political Strategies for Occupational Health

JAMES C. ROBINSON

Based on a wealth of statistical data, legal rulings, and political documents, this comprehensive examination of worker and community battles for occupational safery tells us what has worked in the past and what is likely to work in the future.

$\$ 29.95$ cloth, 235 pages

\section{Risk and Rationality}

Philosophical Foundations for

Populist Reforms

\section{K.S. SHIRADER-FRECHETTE}

Shrader-Frechette, in her newest book, shows why extremist views about risk are unreliable and sketches the reforms needed to set hazard assess. ment and risk evaluation on a publicly defensible foundation.

$\$ 39.95$ cloth, $\$ 15.95$ paper, 272 pages

\section{The Establishment of Communist Rule in Poland, 1943-1948} KRYSTYNA KERSTEY

Translated and annotated by John Micgiel \& Michael H. Bernhard

Foreword by Jan T. Gross

First published underground in Poland in 1984, this inside look at Communist subjugation is now available to the English reader. Kersten's political analysis and bright narrative is inspirational. Societies and Culture in East-Central Europe $\$ 49.95$ cloth, 548 pages
Essays on the

Foundations of Aristotelian Political Science

CARYES LORD \& DAVID O'CONYOR, eds. Here an eclectic group of classicists and political scientists discusses the importance of Aristotle's political and ethical writings-for example, the Poetics, the Rhetoric, the Politics, and ethical and historical treatises - to contemporary approaches in political and social science.

$\$ 39.95$ cloth, 380 pages

\section{Fleeing the Iron Cage}

Culture, Politics, and Modemity in the Thought of Max Weber

\section{LAWREYCE A. SCAFF}

New in paper- -Less a psychobiography than an anatomy of our age, with Weber as guide, diag. nostician, and subject. Carefully crafted and beautifully written, Scaff's is the best book about Weber yet written in English."

$\$ 12.95$ paper, 279 pages

-American Political Science Review

\section{Nested Games}

Rational Choice in Comparative Politics GEORGE TSEBELIS

New in paper-"I have little doubt that this book will be a significant contribution to the discipline and that it will mark the emergence of an important new voice in American political science."

-Robert Putnam, Harvard University Califormia Series on Social Choice and Political Economy \$13.95 paper, 288 pages, illustrated

At bookstores or order toll-free 1-800-822-6657. Visa \& MasterCard only.

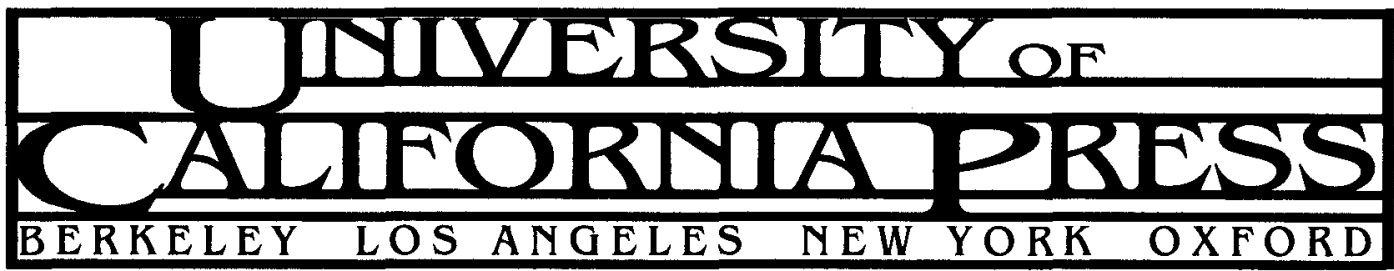




\section{From Agesilaus to Gorbachev}

\section{Agesilaus and the Failure of Spartan Hegemony}

By CHARLES D. HAMITON. "The author paints a broad picture of Spartan internal and foreign policy in the first half of the fourth century B.C. A judicious attempt is made at the application of criteria of psychohistory to the biography of Agesilaus, thus rounding up the historical narrative." - Shalom Perlman, Tel-Aviv University. $\$ 37.95$

\section{The Menshevilks . after October}

Socialist Opposition and the Rise of the Bolshevik Dictatorship

By VLADIMIR N. BROVKIN. New in Paper! "A coherently argued and meticulously researched study of Russian working class history in 1918."-Slavonic and East European Review. Brovkin provides the fullest account to date of the Menshevik party during the first year of Soviet rule. $\$ 14.95$

\section{The Fall of the Athenian Empire}

By DONALD KAGAN. New in Paper!

"A remarkable achievement."-Bernard Knox, The Atlantic. "Political history at its best. ... Kagan shows a remarkable gift for drawing analogies to more recent wars to illuminate this struggle between ancient great powers." - Orbis. $\$ 12.95$

\section{The Nationalization of the Masses}

Political Symbolism and Mass Movements in Germany from the Napoleonic Wars through the Third Reich

By GEORGE L. MOSSE. New in Paper! "[Mosse] has made an important and unique contribution to the literature on nationalism and totalitarianism."-American Historical Review. $\$ 12.95$
Politics/Sense/

Experience

\section{A Pragmatic Inquiry into the}

Promise of Democracy

By TIMOTHY V. KAUFMAN-OSBORN. This book mobilizes the spirit of pragmatism to explore an issue central to modernity: the vitality of democracy in a technological age. $\$ 29.95$

\section{Making All the Difference}

Inclusion, Exclusion, and American Law

By MARTHA MINOW. New in Paper! This sensitive and carefully nuanced argument about how the law should take account of difference is an important contribution to legal theory."-Susan Moller Okin, Brandeis University. $\$ 13.95$

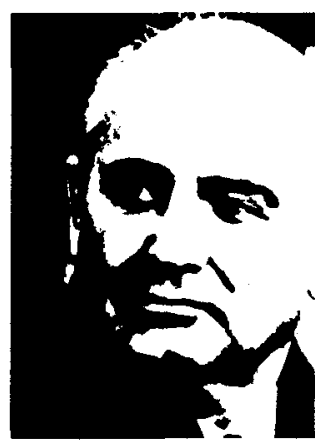

Gorbachev's Struggle for Economic Reform Updated and Expanded Edition

By ANDERS ÅSLUND. "At the top of Washington's reading list." -Newsweek (review of original edition). In this new edition, Åslund has added two new chapters, revised the concluding chapter, and made revisions throughout the book to take into account the current situation in the USSR. $\$ 44.95$ cloth, $\$ 14.95$ paper

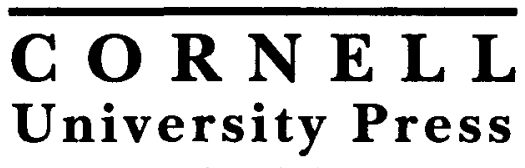

124 Roberts Place / Ithaca NY 14850 


\section{The Johns Hopkins Series in Constitutional Thought}

Sotirios Barber and Jeffrey Tulis, Series Editors

\section{AMERICA'S CONSTITUTIONAL SOUL}

\section{Harvey C. Mansfield, Jr.}

Lately, Harvey Mansfield argues, Americans have begun to value the right of privacy above all others, to consider their rights entitlements, and to forget their pride in governing themselves. In essays on the Reagan "revolution," the conservative movement, religion, affirmative action, the media, and the separation of powers, one of America's leading political theorists and most penetrating thinkers on the Constitution describes what's wrong with American politics today-and what can be done about it.

\$25.95 hardcover
THE ENNOBLING OF DEMOCRACY

The Challenge of the Postmodern Age Thomas L. Pangle

"When a thinker of Thomas Pangle's learning, moral seriousness, and prudence sounds an alarm at the 'civic irresponsibility;' 'spiritual deadliness,' and 'philosophical dogmatism,' of our currently dominant modes of thinking, we need to begin worrying. When he outlines an agenda for reinvigorating our republican experiment, we would do well to pay heed."-Mary Ann Glendon, Harvard Law School

"Presents a challenge that serious thinkers about democracy and education should not evade."-Donald Kagan, Yale University

$\$ 25.95$ hardcover 







\section{NEW FROM LEXINGTON BOOKS}

BEYOND THE SOVIET THREAT The U.S. Army in a Post Cold War Environment James B. Motley

66A timely and well-written book. Careful research combined with an analytical skill resulting from years of military experience and accomplished scholarship, this soldierscholar has captured the essence of problems facing the U.S. Army in the new security environment. Motley's book is a must for those concerned with the role and structure of the U.S. Army in the coming years. 99

- Sam C. Sarkesian,

Loyola University of Chicago

$1991 \quad 0-669-24986-6 \quad \$ 39.95$

\section{THE COLD WAR LEGACY}

Thomas H. Naylor, Duke University

66The turn of history has delivered what

Naylor was among the first to anticipate, an end to the Cold War...He was convinced that a 'revolution' was coming, and it came...If not a prophet, Naylor is certainly an astute observer and analyst. We will benefit by listening to him now.99 - Terry Sanford, U.S. Senate, member of the Committee on Foreign Relations

1991 0-669-24984-X $\$ 21.95$

\section{THE PLACE OF MORALITY IN FOREIGN POLICY}

Felix E. Oppenheim

Provides a thought-provoking examination of an all-too-often overlooked question central to any discussion of international relations and ethics: to what extent is morality relevant in foreign policy decisions? Written to challenge students and experts to explore in what instances morality and moral commitments really matter in international politics.

1991 0-669-21452-3 \$14.95 paper
AMERICAN DEFENSE ANNUAL, 1991-1992

Joseph J. Kruzel, Ohio State University

Now updated to include the latest data from Operation Desert Storm, this is the indispensable guide to the current state of U.S. security policy and how recent dramatic changes in international politics may affect the course of security policy in the 90s. 6 Defense reform is one of a number of topics covered... contains useful source material.99 - Foreign Affairs

October 1991 0-669-27970-6 $\$ 24.95$ paper

\section{DEFENSE BEAT}

\section{The Dilemmas of Defense Coverage}

Loren Thompson, Georgetoun University, Editor

As the recent Gulf war graphically demonstrated, there is an inherent tension between the interests of soldiers and those of the journalists assigned to cover military operations. This book shows how and why this friction between the military and the media, which has persisted since the founding of the republic, has caused profound legal and ethical problems during both war and peace. Thompson begins with an extensive history of U.S. wartime coverage, which traces the evolution of the military-media relationship from the American Revolution to Operation Desert Storm. He then provides thoughtful perspectives on the current status of this relationship written by experts who have experienced it firsthand from both sides.

$1991 \quad 0-669-21842-1 \quad \$ 29.95$

\section{THE INTERNATIONAL POLITICS OF TELEVISION} George H. Quester, University of Maryland This groundbreaking new book examines the impact of television's trans-national reach and its potential to dramatically influence global relations in the future.

1990 0-669-24456-2 \$22.95 paper

For VISA, MasterCard, or American Express

orders, call toll-fiee 1-800-323-7445

Monday through Friday between

9am-5:30pm Eastern Time. 
THE UNITED STATES ARMY Challenges and Missions in the $1990 \mathrm{~s}$

Robert L. Pfaltzgraff, Jr. and

Richard H. Schultz, Jr.

This portrait of the Army's future closely examines the new and emerging issues now confronting U.S. policymakers and military leaders. Bringing together 21 leading security specialists, this book provides incisive analysis of the Army's role within American defense policy in the world today and beyond.

$1991 \quad 0-669-27562-X \quad \$ 39.95$

\section{THE}

\section{INTERNATIONALIZATION OF HUMAN RIGHTS}

David P. Forsythe, University of Nebraska This fascinating exploration of the campaign on behalf of human rights since 1945 shows that this issue, once considered the province of states, has now become an integral part of international relations. Forsythe provocatively probes such hotlydebated questions as what constitutes a human right, whether international action for human rights is a formı of cultural imperialism, and whether there can be international standards for human rights but variation among states in implementing them.

1991 0-669-21117-6 \$16.95 paper

\section{DEATH IN THE BALANCE}

\section{The Debate Over}

\section{Capital Punishment}

Donald D. Hook and Lothan Kahn

66Capital punishment, perhaps more than any other perennial issue of public argument, teaches intellectual humility. No matter which side of the issue you are on, if you do not feel the weakness of your position and see the strengths of the other side, you fully understand neither... if you doubt this is true, read this valuable volume. It is a fine guide to the broad gray areas of argument.99 - George F. Will

1990 0-669-20906-6 \$10.95 paper
STEMMING THE TIDE Arms Control in the Johnson Years Glenn T. Seaborg with Benjamin S. Loeb 66This is a wonderful book of history, memoirs, and analysis and no one from now on will be able to talk about the history of arms control without it.99 - McGeorge Bundy, Special Assistant for National Security Affairs, 1961-66 1990 0-669-24413-9 \$12.95 paper

\section{INSIDE THE APPARAT} Perspectives on the Soviet System from Former Functionaries Uri Ra'anan and Igor Lukes, Boston University

This fascinating history, generated from interviews with defectors from the Soviet Bloc, describes the organization, management, and control of Soviet government and policy. Not directly concerned with missiles, arms, and numbers, the authors instead explore the way the Soviet system actually works.

$1990 \quad 0-669-24226-8$ \$21.95 paper

\section{AMERICAN FEDERALISM Competition Among Governments} Thomas R. Dye, Florida State University According to Dye, a competitive federalism encourages rivalry among state and local governments. Arguing that "eighty thousand governments are better than one," Dye explains why competitive government is better for the citizenry than a single, dangerously powerful, centralized government.

1989 0-669-21474-4 \$16.95 paper

\section{Also Available- THE PSYCHODYNAMICS OF INTERNATIONAL RELATIONSHIPS}

Vamik Volkan, Demetrios A. Julius, and Joseph V. Montville

Volume I: Concepts and Theories

$1990 \quad 0-669-24366-3 \quad \$ 36.95$

Volume II: Tools of Unofficial Diplomacy

$1990 \quad$ 0-669-24368-X $\$ 36.95$ 


\section{New}

\section{BANKS, BORROWERS AND THE ESTABLISHMENT A Revisionist Account of the Intemational Debt Crisis KARIN LISSAKERS}

This first authoritative account of the international debt crisis argues that private banks can and must continue to play a role in world financing - but only after basic weaknesses in both the borrowing institutions and the lending banks are addressed.

$\$ 23.00$

\section{CULTURE WARS}

The Struggle to Define America JAMES DAVISON HUNTER

"Hunter moves beyond familiar nostrums and gestures of despair, offering instead a powerful contribut tion to our conceptual understanding of the deepening cultural crises of our democracy." -Jean Bethke Elshtain, author of Women and War $\$ 25.00$

\section{GALILEO'S REVENGE} Junk Science in the Courtroom

\section{PETER W. HUBER}

"This superb book is so devastatingly funny-it is sad to see so many judges taken in by environmental and health hoaxes with a thin but misleading scientific patina."-Aaron Wildavsky, University of California, Berkeley $\$ 23.00$

\section{Significant}

Basic

\section{OUT OF THE BARRIO}

Toward a

New Politics of Hispanic Assimilation

"A serious, eye-opening and readable book that should go a long way toward dispelling the myths that are influencing policy."

-Ben Wattenberg, American Enterprise Institute $\$ 23.00$

\section{REFLECTIONS OF} AN AFFIRMATIVE ACTION BABY STEPHEN L. CARTER

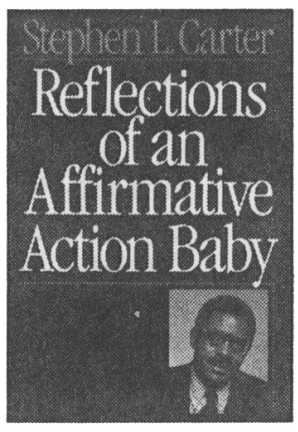

"Carter addresses one of the most vexing issues in contemporary America, the politics and culture of racial preferment. It doesn't matter where you stand: you owe it to yourself to grapple with his arguments."

-Henry Louis Gates, Jr., Hanvard University $\$ 23.00$

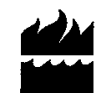

BasicBooks

A Division of HarperCollinsPublishers 10 E. S3rd St., New York, NY 10022 Toll-free with credit card 1-800-331-3761
UNDOING DRUGS

\section{Beyond Legalization}

DANIEL K. BENJAMIN \& ROGER LEROY MILLER

"A devastating indictment of the many ways in which federal officials have abused the 'war on drugs' to trample the Bill of Rights, triple the Justice

Department's budget in a decade, and divert scarce state and local police and prisons away from violent criminals toward victimless moral offenses." -Alan Reynolds, Director of Economic

Research, Hudson Institute $\$ \mathbf{\$ 2 3 . 0 0}$

Now in Paperback!

BUREAUCRACY

What Govermment Agencles Do and Why They Do It

JAMES Q. WILSON $\$ 12.95$

FORKED TONGUE The Politics of Bilingual Education

ROSALIE PEDALINO PORTER $\$ 12.00$

JUSTICE, GENDER \& THE FAMILY

SUSAN MOLLER OKIN $\$ 10.95$

INDEFENSIBLE WEAPONS

The Political and Psychological Case Against Nuclearism Updated and

Expanded Edition

ROBERT JAY LIFTON

\& RICHARD FALK $\$ 15.00$ 


\section{WILLIAVI S. DIETRICH}
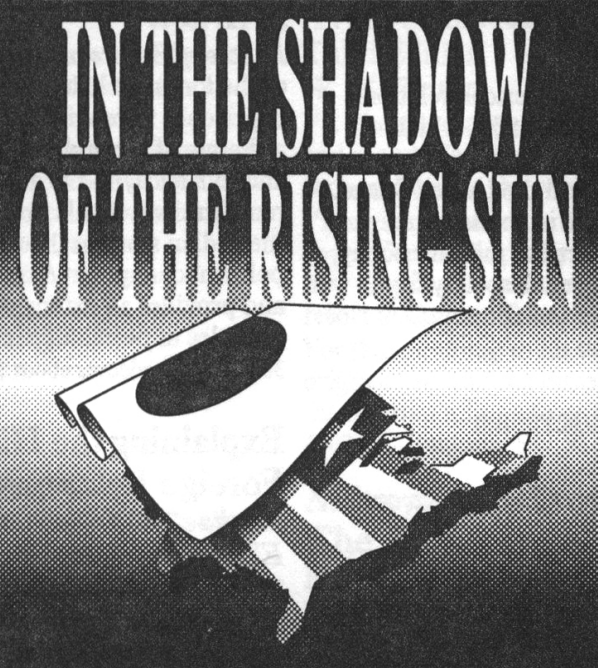

The Political Roots of

\section{American Economic Decline}

\section{Why is the United States unable to compete effectively with Japan? How can America emerge from the shadow of the Rising Sun?}

"The lack of an industrial policy in the United States is the main reason why the U.S. and Japan are trading places in terms of wealth and technological prowess. The economic ideologues of Washington who fear that industrial policy is some kind of heresy should read this book. It accurately explains what industrial policy is, how Japan used it to become the world's richest big nation in terms of per capita income, why we cannot do without it, and what will happen to us as a nation if we continue to cling to obsolete beliefs in laissez faire and so-called free trade."

\section{-Chalmers Johnson, University of California, San Diego}

"This book provides a fair and comprehensive analysis of America's economic problem. Its inherent merits are greatly enhanced by the fact that the author is a businessman-scholar who speaks with authority on many topics. His study will be invaluable for anyone seeking to get a handle on the issue of and the debate over American decline."

$$
\text { -Robert G. Gilpin, Jr., Princeton University }
$$

"In the Shadow of the Rising Sun is a powerful call for a stronger government role to modernize the U.S. economic system. What makes it especially noteworthy is that the call comes from a business executive. When enough other CEOs join Bill Dietrich, we may be on the way to finding our proper place in the world economy." - -Robert Heilbroner, New School for Social Research

\section{0 pages $\$ 24.50 \quad$ ISBN $0-271-00765-6$}

\section{PENN STATE PRESS}

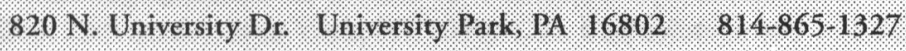




\section{Cambridge University Press}

\section{The United States and the Making of Postwar France, 1945-1954 \\ Irwin M. Wall \\ This is the first study of French-American relations in the critical postwar period, 1945-1954, which makes use of recently opened diplomatic archives and personal papers in France and the United States. Wall examines the American role in French diplomacy, economic reconstruction, military policy, politics, and the reshaping of French society from labor unions to consumer tastes and films. 40217-4 Hardcover $\$ 47.50$}

\section{Governance of the American \\ Economy}

Fohn L. Campbell, F. Rogers Hollingsworth and Leon N. Lindberg, Editors

In this book, nine scholars representing various perspectives examine institutions that govern economic activity in the United States and the dramatic changes they have undergone since the late nineteenth century.

Structural Analysis in the Social Sciences

40257-3 Hardcover $\$ 65.00 / 40827-X$ Paper $\$ 21.95$

\section{Bureaucracy, Economy, and}

\section{Leadership in China}

The Institutional Origins of

the Great Leap Forward

\section{David Bachman}

In this book David Bachman examines the origins of the Great Leap Forward (GLF), a program of economic reform that must be considered one of the great tragedies of Communist China, estimated to have caused the death of between 14 and 28 million Chinese. Bachman proposes a provocative reinterpretation of the origins of the GLF that stresses the role of the bureaucracy.

40275-1 Hardcover $\$ 42.50$

Now in paperback...

Rules, Norms, and Decisions

On the Conditions of Practical and Legal

Reasoning in International Relations and

Domestic Affairs

\section{Friedrich V. Kratochwil}

By assessing the impact of norms on decision making, this book argues that norms influence choices by providing reasons rather than by being causes for action. It approaches the problem via an investigation of the reasoning process in which norms play a decisive role.

Cambridge Studies in Intemational Relations 2

40971-3 Paper $\$ 16.95$

\section{Eclipse of Empire}

D. A. Low

Eclipse of Empire brings together the work of one of the foremost historians of the recent colonial experience to provide comprehensive outline accounts of the end of the British Empire in India and in Africa, and to assess the many sociopolitical ramifications of this process. Professor Low places the Indian story in the much wider context of the vast political changes in Asia through to the present day, and provides an extensive account of the political debacles in post-independence Africa. 38329-3 Hardcover about $\$ 54.50$

\section{Explaining the History of American Foreign Relations Michael F. Hogan and Thomas G. Paterson, Editors}

This collection of essays presents many of the newer, innovative, and stimulating analytical approaches and methods used to study the history of American foreign relations. The essays highlight a variety of conceptual categories, including bureaucratic, dependency, and models, culture, gender, and ideology.

40383-9 Hardcover \$44.50/40736-2 Paper \$13.95

\section{The Invisible State}

The Formation of the Australian State

\section{Alastair Davidson}

The Invisible State is the first major book applying contemporary state theory to Australia. Professor Davidson takes a historical approach, tracing the development of the Australian citizen in the nineteenth century and examining the relationship of the citizen to the state.

Studies in Australian History

36658-5 Hardcover $\$ 65.00$

\section{Talking Politics: A Psychological Framing of Views from Youth in Britain}

\section{Kum-Kum Bhavnani}

This study examines the view of politics presented by young working-class people in contemporary Britain. Bhavnani's analysis, organized by themes such as disposable income and social and personal control, tackles questions of power in the research process and a notion of discursive configurations that is distinct from social representations.

European Monographs in Social Psychology Copublished with La Maison des Sciences de l'Homme 38044-8 Hardcover $\$ 44.50$ 


\section{Cambridge University Press}

\section{Philosophy and Politics \\ G.M. K. Hunt, Editor}

This original collection explores one recurrent theme connecting philosophy and politics: the relation between the nature of man and the structure of society. It does so by concentrating on the topical issue of the market economy as an attempt to resolve the clash between individual autonomy and collective action.

Royal Institute of Philosophy Supplements 26

39597-6 Paper $\$ 16.95$

\section{The Cambridge Encyclopedia \\ of China}

Second Edition

Brian Hook, Editor

Denis Twitchett, Associate Editor

"A fine one-volume source of up-to-date information on China, past and present." - Booklist

"Like a Chinese banquet, the Encyclopedia has a great deal to offer and something for every individual taste... no one can complain that any field has been neglected...It is beautifully produced and presented ... should grace the desk of every interested scholar." - Edmund S. K. Fung, Joumal of Oriental Studies 35594X Hardcover $\$ 49.50$

\section{Lifetimes of Commitment \\ Aging, Politics, Psychology \\ Molly Andrews}

"This is a study which breaks new ground, connecting as it does psychological interpretation, social analysis and biography. Molly Andrews has produced a classic study which represents a major contribution to social psychology and social sciences, but which will also be a distinct interest to a wide lay audience." -Anthony Giddens

This book explores the lives of fifteen British men and women, now between the ages of 70 and 90 , who have dedicated half a century or longer to working for social change and justice.

40280-8 Hardcover $\$ 54.50 / 42249-3$ Paper $\$ 17.95$

\section{Chain Reaction}

Expert Debate and Public Participation in American Commercial Nuclear Power, 1945-1975

\section{Brian Balogh}

Chain Reaction seeks to explain how and why America came to depend so heavily on its experts after World War II, how these experts translated their authority into political clout, and why that authority and political discretion declined in the $1970 \mathrm{~s}$. Brian Balogh's pathbreaking research into the internal memoranda of the Atomic Energy Commission substantiates his argument in impressive historical detail. 37296-8 Hardcover about $\$ 34.50$

\section{The Stages of Economic Growth}

A Non-Communist Manifesto

Third Edition

\section{W. W. Rostow}

"...the most stimulating contribution to political and economic discussion made by any academic economist since the war." -The Economist

"Imaginative, stimulating statement of the economic goals of technologically underdeveloped nations, and how they can be most effectively achieved, without resort to Communism." -The New York Times For those coming to his work for the first time, the original text and the introductions and appendices from earlier editions are included. 40070-8 Hardcover $\$ 47.50 / 40928-4$ Paper $\$ 16.95$

Now in paperback...

The Economy of the Earth

Philosophy, Law and the Environment

\section{Mark Sagoff}

"His book serves as an outstanding example of how applied philosophy should be done."

$$
\text { -Times Higher Education Supplement }
$$

"Any person pursuing a graduate degree in natural resource economics with interests in public policy analysis needs to read and reflect upon Sagoff's book. Any practicing natural resource economist should do the same. This is an important book."

- The American foumal of Agricultural Economics Cambridge Studies in Philosophy and Public Policy 39566-6 Paper \$12.95

\section{Legislatures in the Policy Process}

The Dilemmas of Economic Policy David M. Olson and Michael L. Mezey, Editors

In Legislatures in the Policy Process leading specialists in comparative governments reassess the conventional view that legislatures are either marginal to the policy-making process or becoming increasingly so. Advances in Political Science 38103-7 Hardcover $\$ 39.50$

\section{The Cambridge Handbook of Contemporary China Colin Mackerras and Amanda Yorke} The Cambridge Handbook of Contemporary China draws from numerous sources, official and otherwise, to present up-to-date information on all aspects of Chinese life since 1949, with particular emphasis on the past decade.

38342-0 Hardcover $\$ 37.50$ 


\section{SIPRI Yearbook 1991 \\ World Armaments and Disarmament}

STOCKHOLM INTERNATIONAL PEACE RESEARCH INSTITUTE

This book continues SIPRI's review of the latest developments in nuclear weapons, nuclear explosions, world military expenditure, the international arms trade and arms production, chemical and biological weapons, the military use of outer space, the proliferation of ballistic missile technology, armed conflicts in 1990, US-Soviet nuclear arms control, and conventional arms control in Europe.

1991650 pp.; illus. $\$ 85.00$

\section{Self Interest and Public Interest in Western Politics}

LEIF LEWIN, University of Uppsala;

translated by Donald Lavery

Lewin examines more than two hundred studies of democracy in action from seventeen countries. He looks at the behavior and attitudes of voters, bureaucrats, and politicians, in turn, and shows that the plausible and prevalent theory that egoism rules simply doesn't match the facts.

1991160 pp. paper $\$ 16.95$ cloth $\$ 48.00$

\section{The Critical Theory of Technology}

\section{ANDREW FEENBERG,}

San Diego State University

This book rethinks the relation of technology, rationality, and democracy. It argues that the degradation of labor, as well as manyenvironmental, educational, and political problems, are rooted in the social values that preside over technological development. 1991256 pp. paper $\$ 12.95$ cloth $\$ 32.50$

Prices are subject to change and apply only in the U.S.

To order, send check or money order to:

Social Sciences Marketing, Dept. KLH

To order by phone using major credit cards please call (212) 679-7300, ext. 7106

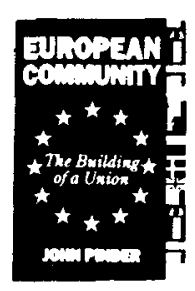

European Community The Building of a Union JOHN PINDER, College of Europe, Bruges

After constructing a complete and coherent view of the Community, this work assesses the political and economic forces for and against unification. Pinder squarely confronts the question whether the Community is likely to become a federal state, and offers his own neo-federalist approach.

1991256 pp. paper $\$ 13.95$ cloth $\$ 47.00$

\section{Liberalism, Community, and Culture}

\section{WILL KYMLICKA, University of Toronto}

"Highly recommended for upper-division undergraduates and above."-Choice

This work presents the liberal view about the nature and value of community culture in an unusually explicit and systematic way, and links it to more familiar liberal views on individual rights and state neutrality.

1991288 pp. paper $\$ 19.95$

\section{Moral Conflict and Politics STEVEN LUKES, European University Institute, Florence}

This fascinating study examines value pluralism and moral conflict and their implications for political thinking and practice. It also discusses the less obvious role of morality in Marxist theory and practice and examines the contributions of contemporary political thinkers, including Vaclav Havel.

1991336 pp. $\$ 69.00$

\section{Divided Societies}

Class Struggle in Contemporary Capitalism

RALPH MILIBAND, City University of New York

"[A] well-written and interesting book."-Choice

In this study Miliband argues for the continued relevance and centrality of class struggle in today's Western societies and examines current examples of class structures and power relationships in the West.

1990 (paper 1991) 288 pp. paper $\$ 14.95$ cloth $\$ 49.95$

\section{Oxford University Press}




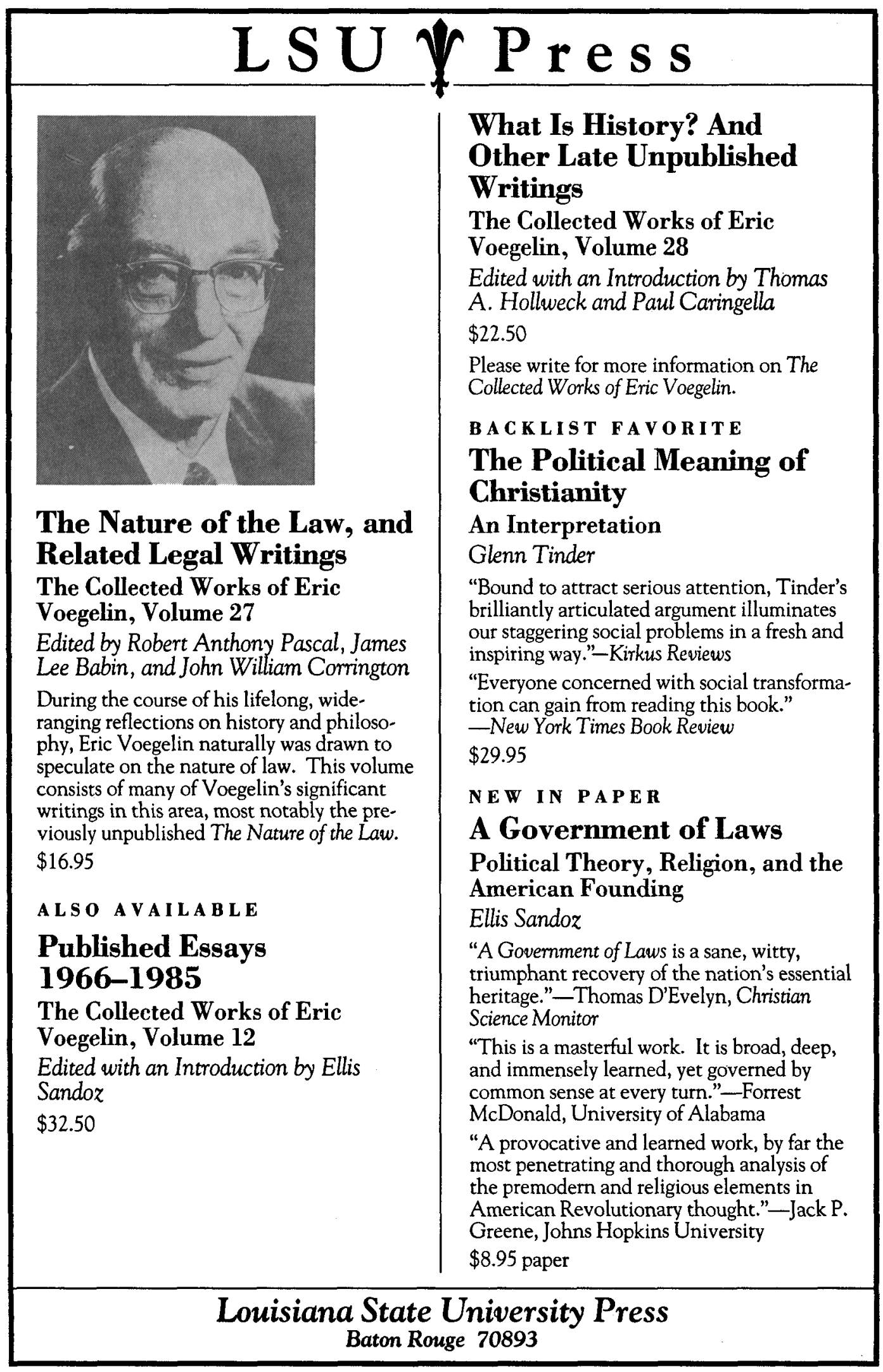




\section{The Best in Political Science.}

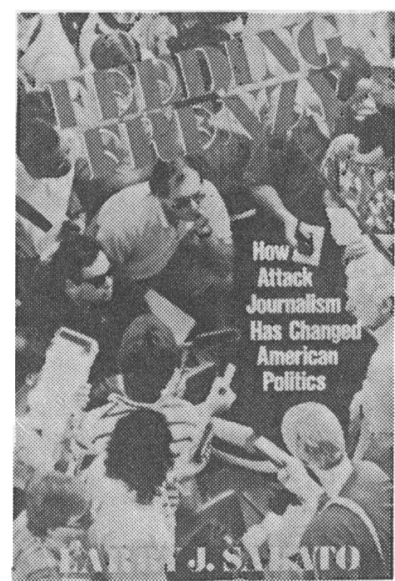

\section{FEEDING FRIENLY}

\section{How Attack Joumalism Has}

Transformed American Politics

Larry J. Sabato, University of Virginia

The media's relentless inquisitions into private lives have left lifelong scars on such figures as John Tower, Geraldine Ferraro, Gary Hart, Dan Quayle, and others. Sabato shows how changes in the libel laws, the increasingly competitive character of the major news organizations, the instantaneous delivery of the news, the domination by television of radio and print, and the star system of modern political reporting fuel the media's omnivorous appetite for personal news and make it extremely difficult to curtail. As the upcoming elections draw near, Sabato's book is a call for the media to return substance to the democratic debate.

1991 0-02-927635-7 $\$ 22.95$

\section{UNDERWRITING DEMOCRACY}

\section{George Soros}

During the early 1970s, Hungarian-born

financier George Soros emerged as one of the world's foremost money managers. Recently he has turned his skills to helping transform the societies of Eastern Europe and the Soviet Union. In this incisive work, Soros recounts his efforts to identify and fund the radical movements which caused the downfall of those communist regimes. He now calls for a restructuring of the Soviet economy around a hard currency, which would give the various republics a real basis on which to trade and establish their autonomy within a more open system.

1991 0-02-930285-4\$22.95

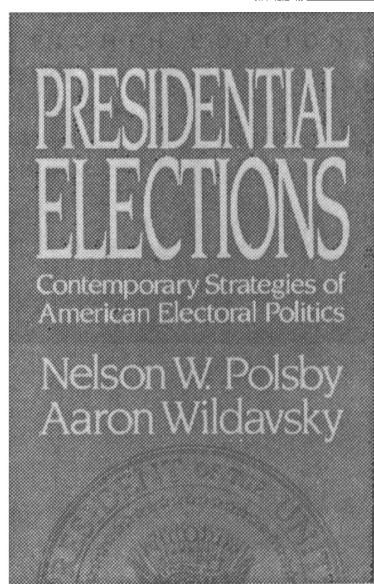

Now in its Eighth EditionPRESIDENTIAL ELECTIONS

\section{Contemporary Strategies of} American Electoral Politics Eighth Edition

Nelson W. Polsby and Aaron Wildavsky This authoritative work, now in its eighth quadrennial edition, is the essential guide to understanding how the most important public official in the world is chosen.

1991 0-02-922786-0 \$14.95 paper

\section{THE KIRKPATRICK MISSION \\ Diplomacy Without Apology: America at the United Nations, 1981-1985 \\ Allan Gerson, American Enterprise Institute}

66 An always absorbing, often gripping account of Jeane Kirkpatrick at the United Nations. It is a story of high political intrigue, the clash of moral and political principles, a story of bureaucratic warfare and global politics. Gerson brings to life the backstage politics of the U.N. and the ideas and interests over which diplomats battle daily... a brilliant war chronicle.99

-Richard Perle, Former Assistant Secretary of Defense for International Security Policy

1991 0-02-911611-2 $\$ 22.95$ 


\section{RIGHTS TALK}

\section{The Impoverishment of}

Political Discourse

Mary Ann Glendon, Harvard University

66If you are going to read only one book in preparation for the 90's-make it this one. It tells you where we are coming from, our present condition, and above all, where we must be going. It is exceptionally well written, by one of the most original thinkers of our times.99

-Amitai Etzioni, author of The Moral Dimension 1991 0-02-911825-5 \$22.95

\section{ILLIBERAL EDUCATION The Politics of Race and Sex on Campus \\ Dinesh D'Souza, American Enterprise Institute}

66No one who has spent any time at an elite academic institution during the past five years will fail to recognize what D'Souza so chillingly chronicles...This courageous book ought to be required reading across the political spectrum.99

-The Washington Post

1991 0-02-908100-9 \$19.95

\section{LABOR WIL RULE Sidney Hillman and the Rise of American Labor Steven Fraser}

66 By placing Sidney Hillman fully in the context of his time, Fraser not only rescues an important American from obscurity, but sheds new light on two subjects central to modern American history-the emergence of the labor movement and the rise and fall of New Deal liberalism.99 -Eric Foner, author of Reconstruction: America's Unfinished Revolution, 1863-1877 1991 0-02-910630-3 \$29.95

\section{SADDAM HUSSEIN \\ A Political Biography}

Efraim Karsh and Inari Rautsi

Saddam Hussein's armies have been routed, but the world will continue to wonder just who Saddam is, and how he came to exercise such power. Here, two specialists on Middle East history and politics have combined their expertise to write the first informed, in-depth political biography of the man who put Iraq on a collision course with the world.

$$
1991 \text { 0-02-917063-X \$22.95 }
$$

\section{SEE HOW THEY RAN The Changing Role of the Presidential Candidate}

Gil Troy, McGill University

Over two centuries and fifty elections, Americans have been complaining about the nature of presidential campaigns and candidates. From the founding of our nation, Americans have wanted a leader who is simultaneously a man of the people and a man above the people. Troy's definitive volume examines every presidential campaign from 1840 to the present to explore why candidates campaign as they do, why Americans complain about it, and what these evolving patterns and changing images tell us about American democracy itself.

November 1991 0-02-933035-1 \$22.95

\section{Now available in paperback-}

\section{CRUCIBLE OF LIBERTY} The Bill of Rights Across Two Centuries Edited by Raymond Arsenault Seven distinguished scholars combine their resources to explore the history and contemporary meaning of the first ten constitutional amendments that continue to spur some of the most intense debates of our time.

October 1991 0-02-901055-1 $\$ 10.95$

\section{PRESIDENTIAL POWER} AND THE

\section{MODERN PRESIDENTS}

The Politics of Leadership from Roosevelt to Reagan

Richard E. Neustadt 1991 0-02-922796-8 $\$ 14.95$

\section{ON TYRANNY BY LEO STRAUSS}

Revised and Expanded Edition

Edited by Victor Gourevitch and

Michael S. Roth

66Must reading for our times.99

-Allan Bloom

1991 0-02-912735-1 $\$ 14.95$

For VISA, MasterCard, or American Express orders, call toll-free $1-800-323-7445$ Monday through Friday between 9am-5:30pm Eastern Time.

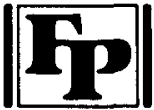




\section{An Ethic of Responsibility in International Relations \\ DANIEL WARNER \\ "A well-argued little book that critically examines some of the most ingrained traditional wisdoms inhibiting the discussion of ethics in international relations.... likely to become a standard work that will inform the debate over the next years." \\ - Friedrich Kratochwil • $1991 \cdot \mathrm{hc} / \$ 30$}

\section{The Gulf, Energy,} and Global Security

Political and Economic Issues

edited by CHARLES F. DORAN and STEPHEN W. BUCK

$1991 \cdot \mathrm{hc} / \$ 35$

\section{The Politics of}

\section{International Law}

U.S. Foreign Policy Reconsidered

DAVID P. FORSYTHE

Forsythe demonstrates how international law really functions in foreign policymaking in

Washington $\cdot 1990 \cdot \mathrm{hc} / \$ 35.00 \cdot \mathrm{pb} / \$ 15.95$

\section{The New International Political Economy}

edited by CRAIG N. MURPHY

and ROGER TOOZE

$1991 \cdot \mathrm{hc} / \$ 33 \cdot \mathrm{pb} / \$ 15.95$

\section{International Politics}

Balance of Power, Balance of Productivity, Balance of Ideologies

RALPH PETTMAN

This introduction to international politics extends the traditional analysis of world affairs to include the international political economy, international society as a whole, and the feminist critique of IR $\bullet 1991 \cdot \mathrm{pb} / \$ 16.95$

\section{The End of the Cold War in Northeast Asia}

edited by STUART HARRIS

and JAMES COTTON

Explores the ramifications of the new, post

Cold-War strategic and economic priorities for

the countries of Northeast Asia $\cdot 1991 \cdot \mathrm{pb} / \$ 18.95$
People, States and Fear, 2nd edition

An Agenda for International Security Studies in the Post-Cold War Era

BARRY BUZAN

From the reviews of the first edition: "A rich, wise, and thought-provoking book." -American Political Science Review $1991 \cdot \mathrm{pb} / \$ 16.95$

\section{Gendered States}

Feminist (Re)Visions of International Relations Theory edited by V. SPIKE PETERSON

Highlights the role of gender in constructing and maintaining the sovereign state system and its related notions of security, autonomy, and identity $\bullet 1992 \cdot \mathrm{hc} / \$ 28.50$

\section{Amilcar Cabral's Revolutionary Theory and Practice \\ A Critical Guide \\ RONALD H. CHILCOTE \\ $1991 \mathrm{hc} / \$ 45$}

\section{Common Security and Nonoffensive Defense A Neorealist Perspective BJ $\phi R N$ M $\phi$ LLER}

Explores the implications of switching to a new type of defense structure that would maintain an undiminished-or even improvedcapability for defense while possessing no offensive capabilities $\cdot 1992 \cdot \mathrm{hc} / \$ 38.50$

\section{Contemporary Political}

\section{Systems}

Classifications and Typologies

edited by ANTON BEBLER and JIM SEROKA

"One of the many strengths of this work is that it points out the many different methods by which a polity can be studied and compared and predictions concerning it can be made."

-Perspectives on Political Science $1990 \cdot \mathrm{hc} / \$ 45$ 


\section{Social Research is More Than Crunching Numbers}

All leading statistical analysis packages will crank out statistical results, but only if you precisely follow elaborate instructions imposed on you by programmers who never do research.

At MlcroCase we think this is backwards. Maybe that's because the company was founded by experienced social scientists who were interested in research, not computers. So we created MicroCase 2.1 , a complete statistical analysis and data management system as easy to operate as your word processor.

MicroCase 2.1 does it your way. Our programmers were never allowed to take the easy way at the expense of the users. They have done all the hard work so that you can concentrate on your research, not on operating the computer.

\section{Don't be a slave to slow programs with arcane command languages!}

MicroCase is fast enough so that you can work interactively at your personal computer. You never have to wait unless, of course, you are working with an immense data base. And MicroCase can handle up to 9,999,999 cases and 32,000 variables!

MicroCase is a screen-oriented program that lets you see relationships on graphics screens, map ecological data, and view internal codebooks from anywhere in the program. Or to print a result, simply touch a single key.

MicroCase also comes with a built-in C.A.T.I. system. In addition to supporting telephone interviewing, the C.A.T.I. lets you give self-administered questionnaires or exams in computer labs, and it allows virtually "mistake proof" data entry.

Why not switch to the analysis system that does more than crunch numbers? Make the switch to MicroCase!

\begin{tabular}{|l|}
\hline MicroCase \\
Order MicroCase now and receive the complete 1990 General \\
Social Survey in MicroCase format at no additional charge.
\end{tabular}

\section{MicroCase Corporation}

\section{I want more from my analysis system!}

Send me the "test drive" demo. Enclosed is $\$ 3$. (Please, no purchase orders.) $3.5^{\prime \prime}$ $5.25 "$

Send me more information on MicroCase. Add me to your mailing list!

For IBM and fully compatible micros with color graphics capacity and $640 \mathrm{~K}$ memory.

Merocane is a registered trademark of Cognitive Development, Inc.

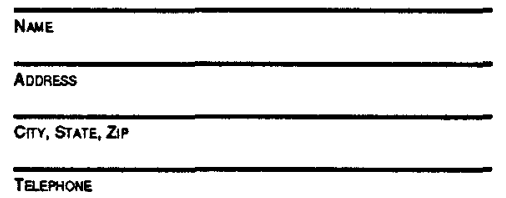

Mall to: MicroCase Corporation

P. O. Box 2180

West Lafayette, IN 47906

Phone: $317-497-9999$ Fax: 317-497-9898 


\section{Crane Russak \\ 1 a Member of Taylor E Francis Group}

\section{The Divided World of the Bolivian Andes: A Structural View of Domination and Resistance \\ Dwight R. Hahn, \\ John Carroll University, University Heights, $\mathrm{OH}$}

Bolivian society is divided, but it is not just between the rich and the poor, or the workers and the owners, or the peasant and the landowner. Bolivia's major division is between two worlds in which values, perceptions and social organization are radically different.

For this study, a mode of production is considered to be composed of three interlocking features. These features, political, ideological, and economical, should be seen as the pervasive themes that, together, combine in various effects, which in turn compose the reproducing thing called 'society'. The book demonstrates that the Bolivian state was unable to overcome the contradiction posed by indigenous ideology, which was reactive and resistant to the intrusion of capitalist reactions to production in the countryside.

$$
\begin{gathered}
1991 \cdot 150 \text { pages } \\
0-8448-1695-7 \text { Hardcover } \$ 47.00
\end{gathered}
$$

\section{State, Class and the Nationalization of the Mexican Banks \\ Russell White, Ph.D., \\ Latin American Consulting, Inc., Kent, WA}

This book provides an analytical history of Mexican banks and the transformation of commercial, bank and finance capital. It examines the relevance of Mexican financial history as compared to the decision to nationalize the banks. By analyzing the role of the State in relation to capital, the author addresses important political concepts about the nature of the State and the nature of class fractions of capital. This book specifically addresses the issue of intra-class political-economic power. The author is particularly interested in examining the development, maturation, and power of the financial fraction of the bourgeoisie.

$$
\begin{gathered}
1991 \bullet 224 \text { pages } \\
0-8448-1698-1 \text { Hardcover } \$ 47.00
\end{gathered}
$$

To Order, Call, TOLL-FREE, 1-800-821-8312 Or Write to: Crane Russak, c/o Taylor \& Francis, 1900 Frost Road, Suite 101, Bristol, PA 19007-1598 


\section{Michigan Michigan Michigan}

\section{Political ANalysis}

An Annual Publication of the

Methodology Section of the American

Political Science Association

VOLUME 2, 1990

\section{Edited by James A. Stimson}

Associate editors: Christopher A. Achen, University of Chicago; Nathaniel L. Beck, University of California, San Diego; Stanley Feldman, University of Kentucky; John A. Ferejohn, Stanford University.

Now in its second year, Political Analysis publishes scholarly articles on topics related to all areas of political science methodology as it is broadly defined, including statistical models, modeling, measurement, and research design. Volume 2 of Political Analysis addresses such issues as fallacy in comparative politics inquiry, classification of interstate conflict outcomes, and instrumental variables models and models of dimensionality, and presents a debate on the usefulness of R-square. The volume joins its predecessor as a publication of great value in communicating new methodical research.

cloth $\$ 42.50$

\section{Also available}

\section{VOLUME 1, 1989}

cloth $\$ 42.50$

Volumes are available at a $10 \%$ discount to members of the Methodology Section of the American Political Science Association.

Michigan residents, include $4 \%$ sales tax. 


\section{NEW AND EXPANDED EDITION \\ RATIONALISM IN POLITICS AND OTHER ESSAYS}

\section{By Michael Oakeshott \\ Foreword by Timothy Fuller}

Michael Oakeshott's work is beginning to attract the attention it richly deserves and this excellent new edition, including very important essays that have been inaccessible, will surely augment the growing interest in his thinking. It will be particularly valuable to be able to consult these essays in the light of On Human Conduct. -Richard Flathman, Johns Hopkins University

Rationalism in Politics has established Michael Oakeshott as the greatest British philosopher of conservative disposition. First published in 1962, this new and expanded edition includes six additional essays (one previously unpublished), a full index, and a foreword and bibliography by Timothy Fuller. This edition also arranges the essays thematically so that the reader will be better able to grasp the relation between the arguments of these essays and Oakeshott's other major works.

$558+$ xxvi pages. Preface to the 1st Edition, foreword, bibliography, index.

Hardcover $\$ 24.00$

Paperback \$7.50

0-86597-094-7 0-86597-095-5

LibertyPress, 1991

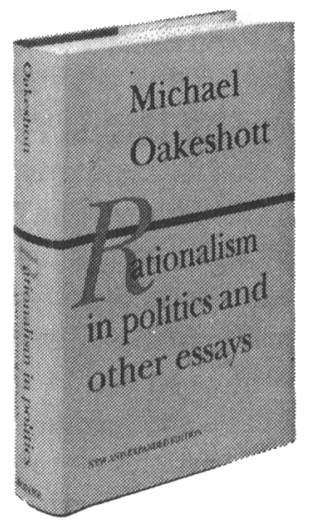

\section{THE STATE OF THE UNION: Essays in Social Criticism}

\section{By Albert Jay Nock}

\section{Edited and with a Foreword by Charles $\mathrm{H}$. Hamilton}

"In a time of raucous and often mindless debate, it is a double pleasure to read Albert J. Nock-for what he says and for the way he says it. Here is social and intellectual criticism at its best, from a thinker who will surely climb in due course to his proper place in the American pantheon." -Jacques Barzun

$340+x x x$ pages. Foreword, selected bibliography, acknowledgments, index. $\begin{array}{lr}\text { Hardcover } & \$ 20.00 \\ \text { Paperback } & \$ 7.50\end{array}$ 0-86597-092-0 0-86597-093-9 LibertyPress, 1991

Prepayment required on all orders not for resale. We pay book rate postage on prepaid orders. Please allow approximately 4 weeks for delivery. All orders from outside the United States must be prepaid in U.S. dollars. To order, or for a copy of our current catalogue, please write:

Liberty Fund, Inc.

Department H106

7440 North Shadeland Avenue

Indianapolis, IN 46250 


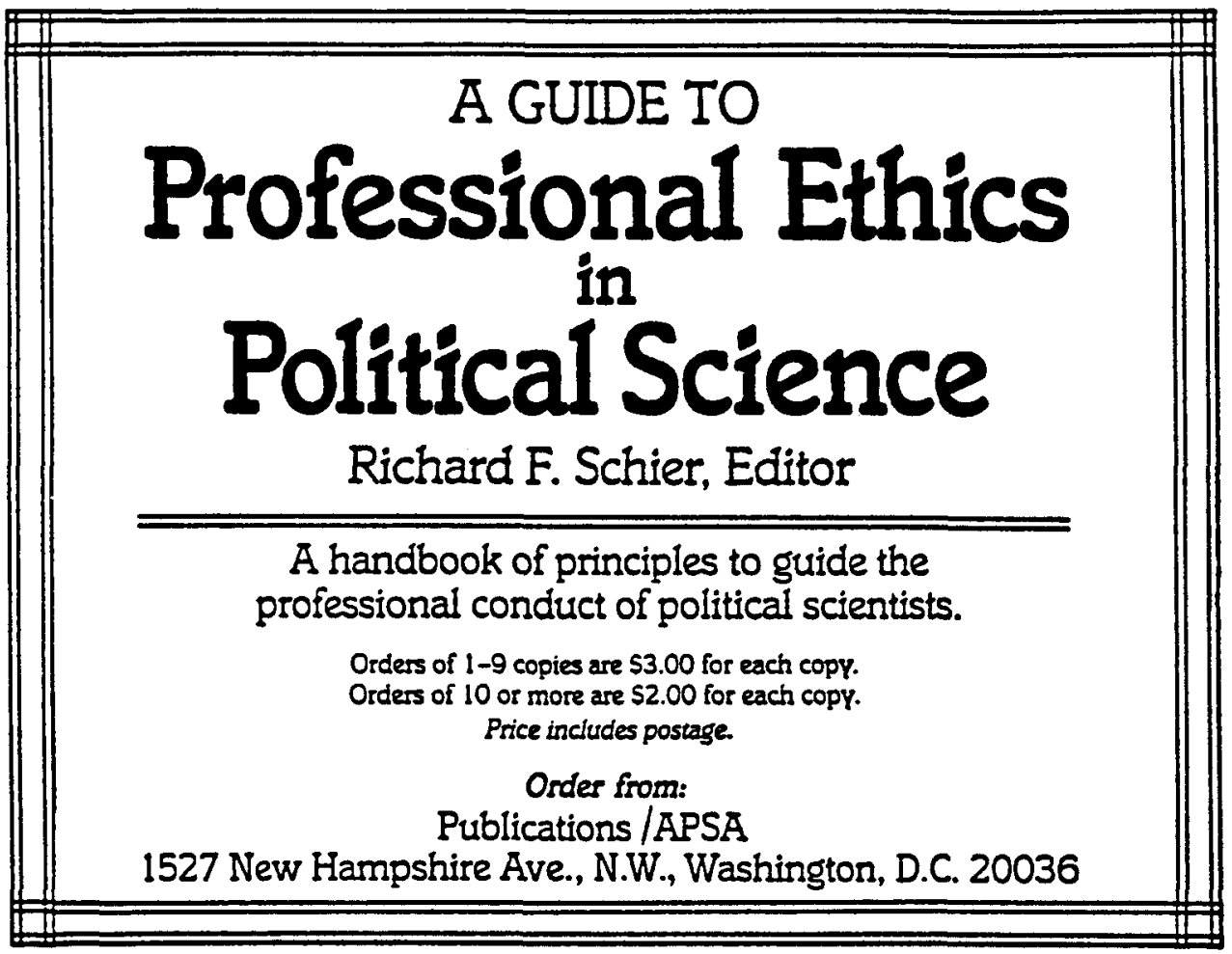

\section{THE BITTERSWEET CENTURY Speculations on Modern Science and American Democracy by Paul N. Goldstene}

"In The Bittersweet Century Goldstene exposes the elitist core of liberal thought and practice with a radical critique that focuses on the opposition of liberals and conservatives alike to a genuinely democratic and egalitarian society. It is a powerful and penetrating indictment of liberalism in theory and practice ... scintillating in analysis and exhilarating in style."

Rick Tilman, Journal of Economic Issues, September 1990

"For those willing to give it careful reading and study ... The Bittersweet Century will serve as a useful springboard for understanding the role of science and technology in the current public policy environment of the late twentieth century."

Dennis L. Soden, Perspectives on Political Science (Winter, 1990)

Paul N. Goldstene is Professor of Government at California State University, Sacramento. He is the author of The Collapse of Liberal Empire: Science and Revolution in the Twentieth Century (Yale University Press, 1977; Chandler \& Sharp, 1980) and Democracy in America: Sardonic Speculations (Bucknell House, 1988).

256 pp., 6x9," notes, indexes (names \& topics)

ISBN 0-88316-560-0 (cloth) \$22.95 ISBN 0-88316-559-7 (paper) \$12.95

Other titles from Chandler \& Sharp include: The Enterprise of Public Administration (Dwight Waldo), Beyond Liberalism, Where Relations Grow (Henry Kariel), Understanding Politics (William Stewart), and two books by Jane Bayes-Minority Politics and Ideologies in the U.S. and Ideologies and Interest-Group Politics.

Chandler \& Sharp Publishers, Inc.

11A Commercial Blvd., Novato, CA 94949 • (415) 883-2353 


\section{AGENDA SETING}

\section{THE REASONING VOTER}

Communication and Persuasion in

Presidential Campaigns

Samuel L. Popkin

"Popkin's considerable achievement is to consolidate into a single framework the insights provided by the sociological study of campaigns, the economic analysis of information seeking, and the psychology of judgment and choice. The book is ambitious, original, and important, not least because it enriches our understanding of the peculiar way we Americans choose a president." - Donald R. Kinder, coauthor of News That Matters: Television

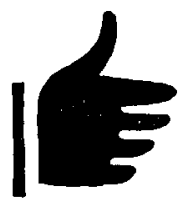
and American Opinion

"A brilliant and elegantly written book that will change the way we view elections." -E. J. Dionne, Jr., outhor of Why Americans Hate Politics Cloth $\$ 19.95272$ pages

\section{American Politics and Political Economy series}

\section{THE HOLLOW HOPE}

Can Courts Bring About Social Change? Gerald N. Rosenberg

This is an exciting, important book, making a powerful case for the ways the U.S. courts are embedded within and constrained by larger social and political processes." - Jane Mansbridge, author of Beyond Self Interest

Cloth $\$ 29.95424$ pages

\section{SHIFTING THE BURDEN}

The Struggle over Growth and Corporate Taxation

\section{Cathie J. Martin}

"A trenchant analysis of the perennially important question of the relationship between governmental strategy, corporate taxation, and economic growth."

- Aaron Wildavasky

Paper $\$ 15.95260$ pages

\section{GaINING ACCESS}

\section{Congress and the Farm Lobby,} 1919-1981

\section{John Mark Hansen}

Drawing on rational choice theory, this comprehensive anolysis of American agricultural politics illustrates when, how, and why interest groups goin and lose influence in the policy deliberations of the United States Congress. Paper $\$ 15.95232$ pages

\section{Making local NeWS Phyllis Kaniss}

"A sophisticated and lucid explanation of the symbolic, political, and economic factors that shape the news closest to home. A first in its field and a must for students and scholars." - George Gerbner, coauthor of Communications Technology and Social Policy

Cloth $\$ 24.95248$ pages

\section{THE CLOSING DOOR}

Conservative Policy and Black Opportunity Gary Orfield and Carole Ashkinaze

With a Foreword by Andrew Young

This powerful and disturbing portrait of the decline of black opportunity in America reveals not only how conservative racial policies and market solutions failed in the city of Atlanta, but also how many gains made in that cradle of the civil rights movement were lost during the last decade.

Cloth \$22.50 274 pages

12 line drowings, 33 tables

\section{THE FOUCAULT EFFECT}

Studies in Governmentality

Edited by Graham Burchell, Colin Gordon, and Peter Miller

In this long-awaited sequel to Power/Knowledge Foucault examines the activity of government both in its present form and within a historical perspective. Two lectures by and an interview with Foucault are supplemented here with essays on the topic of governmentality by internationally renowned scholars.

Paper $\$ 19.95320$ pages 


\section{READING - CHICAGO}

THE TREND OF ECONOMIC THINKING

Essays on Political Economists and

Economic History

\section{F. A. Hayek}

Edited by W. W. Bartley III and Stephen Kresge

This volume captures Hayek's views on Mandeville, Hume, Cantillon, Adam Smith, and Henry

Thornton and provides a fascinating introduction to the historical context of political economy and the evolution of monetary practices.

Cloth $\$ 45.00388$ pages

The Collected Works of F. A. Hoyek, Volume 3

Now in Poper

THE FATAL CONCEIT

The Errors of Socialism

F. A. Hayek

Edited by W. W. Bartley, III

"A brilliant summary of his life's work."

- Ronald Bailey, Forbes

Paper $\$ 12.95194$ pages

The Collected Works of F. A. Hayek, Volume 1

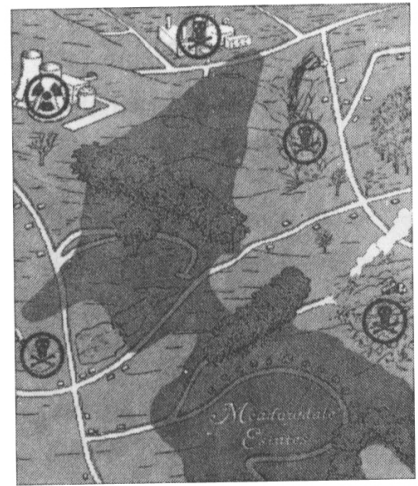

\section{HOW TO LIE WITH MAPS}

\section{Mark Monmonier}

This lively, cleverly illustrated essay on the use and abuse of maps teaches us how to evaluate maps critically and promotes a healthy skepticism about these easy-10-manipulate models of reality.

"More than a book on mendacity, How to Lie with Maps is really a primer on the fundamentals of map-making. "-Christopher LehmannHaupt, The New York Times

Poper \$12.95 184 pages 7 holftones, 95 maps
Now in Paper

JOHN LOCKE'S LIBERALISM Ruth W. Grant

"A remarkably clear and crisply written analytical account of Locke's nomative political theory." - James Tully, Canadian Journal of Political Science

Paper \$13.95 230 pages

\section{Hegel's CRITIQUe Of Liberalism}

Rights in Context

Steven B. Smith

"A learned treatise, lucidly written, presenting in a differentiated and sophisticated way a spirited yet critical account of Hegel's views." - Shlomo Avineri, Review of Polifics

Paper \$14.95 272 pages

\section{NietzSCHE'S NEW SEAS}

Explorations in Philosophy, Aesthetics, and Politics

Edited by Michael Allen Gillespie and Tracy B. Strong

"Of interest to all students of Nietzsche, especially those interested in breaking down the boundaries between philosophy, aesthetics, and politics in his thought." - Ethics

Paper $\$ 13.95248$ pages

\section{Peasants against the state}

The Politics of Market Control in Bugisu, Uganda, 1900-1983

Stephen G. Bunker

With a new Afterword

"It is through detailed, careful, theoretically sophisticated but microbased field studies such as this one that our understanding of African politics . . . and our ability to resolve current problems will improve." - James S. Wunsch, American Political Science Review

Poper $\$ 14.95302$ pages

\section{SRI LANKA-ETHNIC FRATRICIDE AND THE DISMANTLING OF DEMOCRACY}

\section{S. J. Tambiah}

"An excellent and thought-provoking book, for anyone who cares about Sri Lanka."

- Paul Sieghart, Los Angeles Times Book Review Poper $\$ 10.95216$ pages 


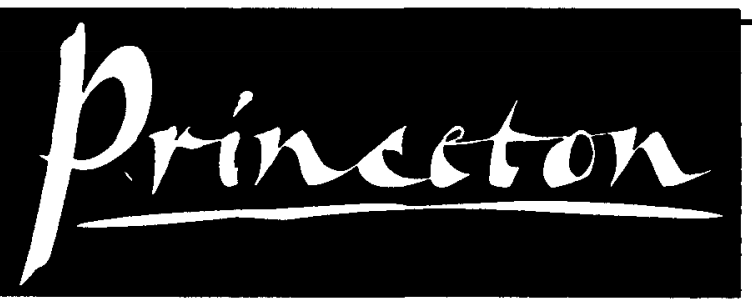

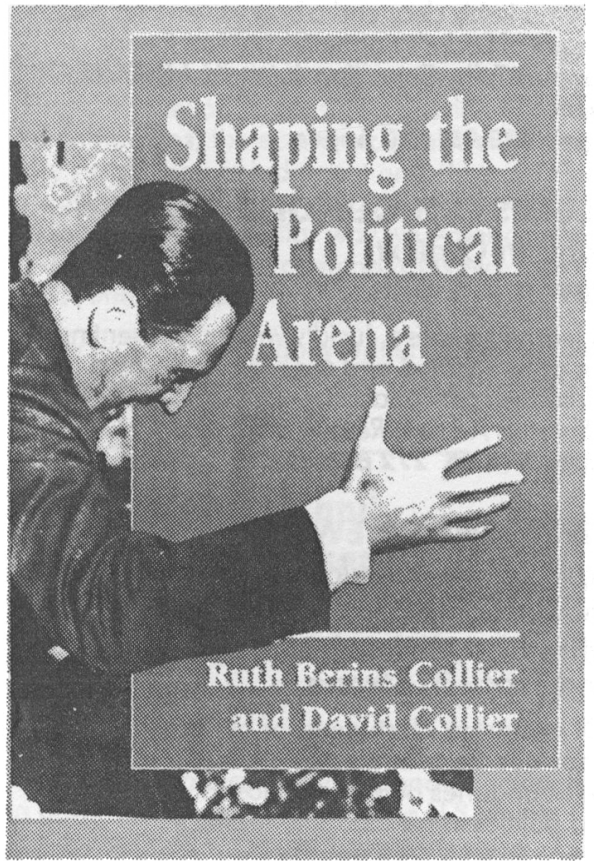

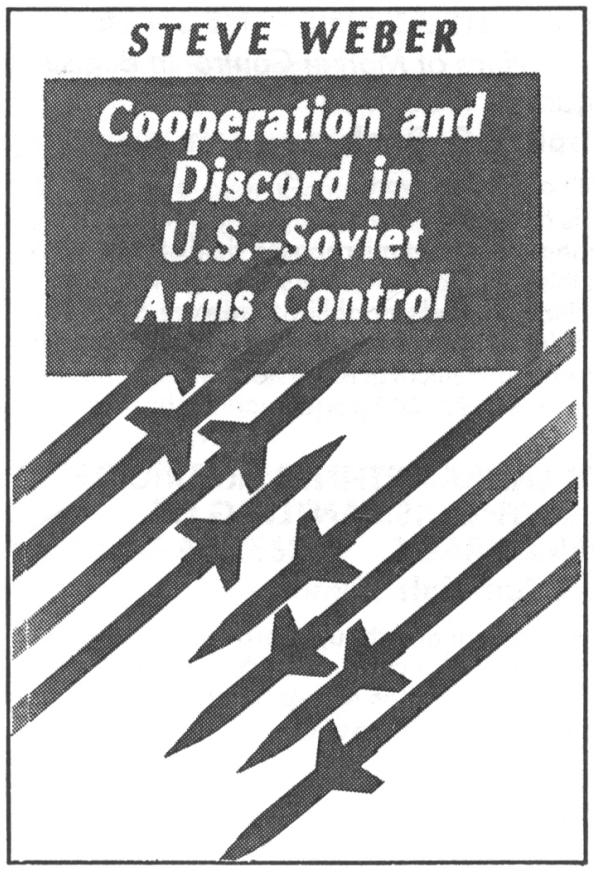

\section{Ruth Berins Collier and David Collier}

Illuminating the dynamics of political change in Latin America during the twentieth century, this ambitious work traces the impact of a "critical juncture": a period of fundamental political reorientation in which countries are set on distinct trajectories of change. The authors focus on the response of national states to the newly radicalized working class and organized labor movements that arose in the course of capitalist modernization. They examine the incorporation of the labor movement, showing how national leaders-including Peron in Argentina and Vargas in Brazil-sought to impose a new political and institutional framework on working-class politics.

"This work is a tour de force. it will not only be one of the most important books on Latin America in the next decade, but will also be a major landmark in comparative politics and political development." -Robert Kaufman, Rutgers University Paper: \$19.95 ISBN 0-691-02313-1 Cloth: $\$ 75.00$ ISBN 0-691-07830-0

\section{Steve Weber}

If international cooperation is difficult to achieve and to sustain, why then have two rival superpowers been able to cooperate in placing limits on their central strategic weapons systems? Extending an empirical approach to game theory-particularly that developed by Robert Axelrod-Steve Weber offers a new theory explaining the range of cooperation exhibited in three critical U.S.-Soviet arms control cases: efforts to limit anti-ballistic missile systems, MIRV warheads, and anti-satellite weapons.

Weber concludes with a set of policy-relevant prescriptions recommending that the superpowers refocus their arms control efforts on joint research rather than continue to emphasize quantitative limitations on weapons systems. Cloth: $\$ 35.00$ ISBN 0-691-07837-8 


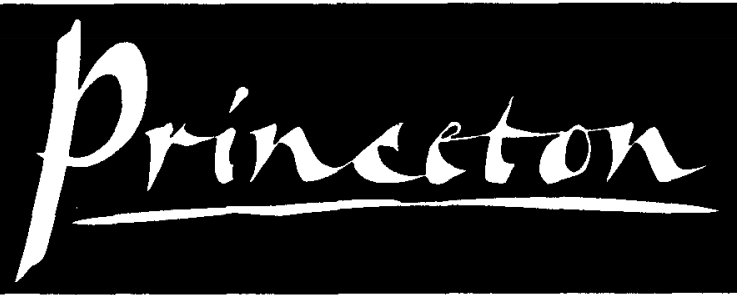

\section{The Rise of the Therapeutic State Andrew J. Polsky}

Assuming that "marginal" citizens cannot govern their own lives, proponents of the therapeutic state urge casework intervention to reshape the attitudes and behaviors of those who live outside the social mainstream. Here Andrew Polsky investigates the emergence and persistence of the therapeutic state- the broad network of public agencies that adopt the casework approach. He shows how ideas and politics combined to establish the casework approach as a core element in American social policy. Further, he contends that the therapeutic state has failed to produce the results advocates have promised and has subverted basic democratic values.

"The Rise of the Therapeutic State interprets the development of social policy from a perspective that has often been noted but never elaborated in such a sustained manner. The author has made a forceful normative argument about the contradictions between the therapeutic approach and democracy."-Margaret Weir, Harvard University

Cloth: $\$ 35.00$ ISBN 0-691-07878-5

\section{New in paperback Constitutional Diplomacy With a foreword by J. William Fulbright}

Challenging those who accept or advocate executive supremacy in American foreign-policy making, Constitutional Diplomacy proposes that we abandon the supine roles often assigned our legislative and judicial branches.

"Although Constitutional Diplomacy was written before an American line was drawn in the sands of the Arabian Peninsula after Iraq took over Kuwalt, it is hard to imagine a book that is more prescient and provocative about the huge military buildup in the Persian Gulf. ... Glennon writes as if he had a crystal ball that foretold the events now unfolding in the Persian Gulf." - Herbert Mitgang, The New York Times

Now in paper: \$14.95 ISBN 0-691-02305-0

\section{Revised paperback edition The Other Walls The Arab-Israeli Peace Process in a Global Perspective Harold H. Saunders}

Drawing on intensive firsthand experience gained during the most successful years of Arab-lsraeli peace negotiations, Harold Saunders explains the complexities of the peace process: it was not just a series of negotiated agreements but negotiation embedded in a larger political process. In the wake of the Gulf War Saunders suggests how insights from earlier Arab-Israeli peace negotiations can lead to a broader regional process.

Paper: \$14.95 ISBN 0-691-02337-9

Cloth: \$45.00 ISBN 0-691-07888-2

\section{Princeton University Press}

41 WILLIAM ST. • PRINCETON, NJ 08540 • (609) 258-4900 ORDERS: 800-PRS-ISBN (777-4726) • OR FROM YOUR LOCAL BOOKSTORE 


\section{Chatham House Publishers \\ Box One, Chatham, New Jersey 07928 \\ Telephone: (201) 635-2059}

The Bush Presidency: First Appraisals

Colin Campbell, S.J., Georgetown University, and Bert A. Rockman, Brookings Institution "First impressions are often prescient. These first appraisals of the Bush Presidency must be given serious attention by scholars, citizens, and hopefully members of the Bush administration. It's a most commendable and highly instructive model of political analysis."

Mark P. Petracca, University of California, Irvine

0-934540-9I-8 \$16.95 paper

9-934540-90-X \$25.00 cloth

\section{Dogmas and Dreams: Political Ideologies in the Modern World}

Nancy S. Love, Pennsylvania State University

"A first-rate collection of modern political writings. Perfect for introduction to theory courses." 0-934540-84-5 \$19.95 paper

William P. Kreml, University of South Carolina

\section{The Moral Imagination and Public Life: Raising the Ethical Question}

Thomas E. McCollough, Duke University

"McCollough's perspective on the public life is communal, based on a vision of the informed and responsible citizen involved in a truly democratic politics. His work will add a stimulating dimension to courses on modern democratic politics, public policy, and ethics in public life." 0-934540-85-3 \$14.95 paper $\quad$ W.J. Siffin, Indiana University

\section{The Postmodern President: George Bush Meets the World. 2d ed.} Richard Rose, University of Strathclyde

"Richard Rose has produced an exceptional book, not just about Presidents but also about how they connect - or fail to connect-with Washington and the world. His unique comparative approach, blending process with politics and policy, results in an insightful, engaging treatment of the Presidency and its place in the American system."

0-934540-94-2 \$19.95 paper I.M. Destler, University of Maryland

\section{The President as Interpreter-in-Chief}

Mary E. Stuckey, University of Mississippi

"Concise and well written, observers and teachers of the Presidency will find this book a valuable resource. It's use in courses on the American Presidency, media and politics, political communication, and American politics will enrich student understanding of contemporary mediated politics and future challenges to democracy."

0-934540-92-6 \$14.95 paper Robert E. Denton, Jr., Virginia Polytechnic Institute

\section{The World of the Policy Analyst: Rationality, Values, and Politics}

Robert A. Heineman, Alfred University, William T. Bluhm, University of Rochester, et al. "A valuable contribution to a literature that ought to grown on how we can build bridges between scholarship and practice in public affairs." Richard P. Nathan, University at Albany 0-934540-75-6 \$14.95 paper

For further information about these and forthcoming titles, please contact the publisher, Edward Artinian, CHATHAM HOUSE PUBLISHERS, Box One, Chatham, NJ 07928. Phone: (201) 635-2059. Fax: 635-9366 


\section{INSTRUCTIONS TO CONTRIBUTORS}

The American Political Science Review aims to publish scholarly research and writing of exceptional merit. Contributions must demonstrate the highest standards of excellence in conceptualization, exposition, methodology, and craftsmanship. Because the Review reaches a diverse audience of scholars and practitioners, contributors must demonstrate how their analysis or exposition illuminates a significant research problem, or answers an important research question, of general interest in political science.

\section{Article Manuscripts}

Article manuscripts should be submitted to the Managing Editor, Professor Samuel C. Patterson, American Political Science Review, Department of Political Science, Ohio State University, 112 Derby Hall, Columbus, Ohio 43210-1373. Four copies must be submitted, and none can be returned. Manuscripts must be typed double-spaced, on one side of the paper only, and include an abstract of no more than 150 words. The author's name and affiliation should not appear on the copies submitted, but only on a separate covering sheet. In general, the Review considers manuscripts of up to 30 pages in length. Moreover, the Review does not consider manuscripts submitted to other publications.

Manuscripts should be prepared following the guidelines of the Style Manual for Political Science, a publication of the American Political Science Association's Committee on Publications. It is available from the association's office. Otherwise, authors should follow the Chicago Style Manual and the example of recent issues of the Review. Graphs and tables should be presented on separate pages, with their location in the manuscript indicated, e.g., the notification "Table 1 about here," at the proper places.

\section{Book Reviews}

Books intended for review and all book review correspondence should be sent to the
Book Review Editor, Professor Helen $M$. Ingram, American Political Science Review, Department of Political Science, University of Arizona, Social Sciences 315, Tucson, Arizona 85721.

\section{Other Correspondence}

Information, including news and notes, for the Association's news journal PS, should be sent to Dr. Robert J-P. Hauck, Editor, American Political Science Association, 1527 New Hampshire Avenue, N.W., Washington, D.C. 20036. Advertising, reprint, and circulation correspondence should be sent to the Executive Director at the Washington office. Domestic claims for nonreceipt of issues must be made within four months of the month of publication; overseas claims, eight months. Advertising information and rates are available from Ann V. Peyser, Advertising Manager, APSA, 1527 New Hampshire Avenue, N.W., Washington, D.C. 20036.

\section{Indexing}

Articles and notes appearing in the Review before the June 1953 issue were indexed in The Reader's Guide to Periodical Literature. Current issues are indexed by International Political Science Abstracts, United States Political Science Documents, and Social Sciences and Humanities Index. Microfilm of the Review, beginning with Volume 1 , may be obtained from University Microfilms, 300 North Zeeb Road, Ann Arbor, Michigan 48106. A Cumulative Index of the Review, Volumes 1-62, 1906-1968, also may be obtained from University Microfilms. Articles appearing in the Review are listed in $A B C$ Pol Sci and Current Contents: Behavioral, Social \& Management Sciences. Book Reviews are indexed in Book Review Index. 


\section{CONTENTS}

\section{ARTICLES}

Relative Gains and the Pattern of International Cooperation

Duncan Snidal

Nuclear Deterrence, Counterforce Strategies, and the Incentive to Strike First

R. Harrison Wagner

European Party Loyalties Revisited

Bradley M. Richardson

The Political Impact of Economic Crisis in Latin America in the $1980 \mathrm{~s}$

Karen L. Remmer

The Dynamics of Political Control of the Bureaucracy

B. Dan Wood \& Richard W. Waterman

Street-Level Political Controls over Federal Bureaucracy

John T. Scholz, Jim Twombly \& Barbara Headrick

Business Political Power: The Case of Taxation

Dennis P. Quinn \& Robert Y. Shapiro

Moral Education and the "Tie That Binds" in Liberal

Political Theory

David C. Paris

RESEARCH NOTE

Measuring Value Change in Western Industrialized Societies:

The Impact of Unemployment

Harold D. Clarke \& Nitish Dutt

CONTROVERSIES

Conceptual Problems in Theorizing About International Conflict

James D. Morrow, Barry L. Price \& Roslyn Simowitz

Industrial Concentration, Country Size, and Trade Union

Membership

John D. Stephens \& Michael Wallerstein

On Dimensionalizing Roll Call Votes in the U.S. Congress

Keith T. Poole, Howard Rosenthal \& Kenneth Koford

BOOK REVIEWS

The Supreme Court and Democratic Accountability . . . . . . . . . . . . . 983

Political Theory ... . . . . . . . . . . . . . . . . . . . . . . . . 989

American Politics . . . . . . . . . . . . . . . . . . . . . . . 1013

Comparative Politics . . . . . . . . . . . . . . . . . . . . . . . . . 1042

International Relations . . . . . . . . . . . . . . . . . . . . . . 1070 